\title{
COMMUNITY ENERGY PLANNING IN ONTARIO AND BRITISH COLUMBIA: CLIMATE ACTION AT A MUNICIPAL PLANNING LEVEL
}

\author{
by \\ Jessica Brodeur \\ B.A., University of British Columbia, 2014 \\ A Masters Research Paper \\ presented to Ryerson University \\ in partial fulfilment of the requirements for the degree of \\ Masters of Planning \\ in Urban Development
}

Toronto, Ontario, Canada, 2019

(C) Jessica Brodeur 2019 


\section{Author's Declaration}

I hereby declare that I am the sole author of this MRP. This is a true copy of the MRP, including any required final revisions.

I authorize Ryerson University to lend this paper to other institutions or individuals for the purpose of scholarly research.

I further authorize Ryerson University to reproduce this MRP by photocopying or by other means, in total or in part, at the request of other institutions or individuals for the purpose of scholarly research.

I understand that my MRP may be made electronically available to the public. 


\title{
COMMUNITY ENERGY PLANNING \\ IN ONTARIO AND BRITISH COLUMBIA: \\ CLIMATE ACTION AT A MUNICIPAL PLANNING LEVEL
}

\author{
(C) Jessica Brodeur, 2019 \\ Master of Planning \\ In \\ Urban Development \\ Ryerson University
}

\begin{abstract}
Community Energy Planning (CEP) is a process that allows municipalities to develop and implement local climate action, meet carbon reduction goals, and ensure a steady supply of clean energy. This MRP compares CEP in four municipalities in Ontario and British Columbia, to examine the reasons that led municipalities to undertake CEP and the roles that the municipalities undertook in the process. By using a policy comparison and interviews with Subject Matter Experts, the role that the municipality played to develop and implement CEP, and the role of the CEP within the community were evaluated. The municipalities studied were seen to have undertaken the expected roles to varying degrees and with various methods.
\end{abstract}

Key Words:

An article on energy and emissions planning in Canadian municipalities, used the key words: community energy planning, climate action, energy policy, local environmental planning 


\section{List of Figures}

Table 1: City size and population comparison

Table 2: Matrix of Conditions/Context for Successful CEP across research.

\section{List of Appendices}

Appendix A: Interview questions 


\section{Table of Contents}

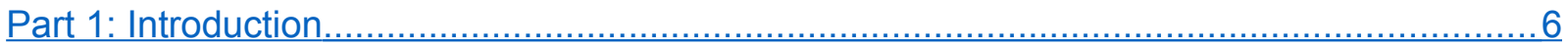

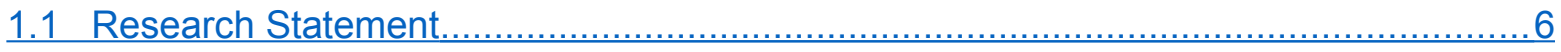

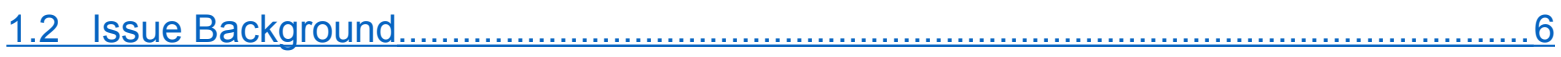

1.2.1 Approaching the Problem at a Municipal Scale .....................................................

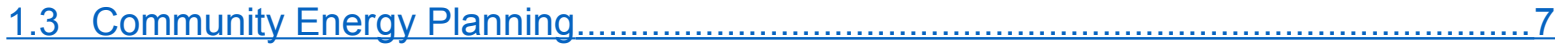

1.3.1 What are Community Energy Plans? .............................................................

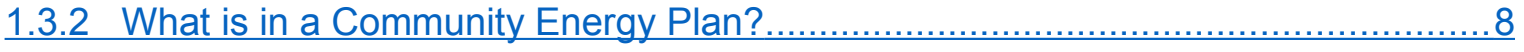

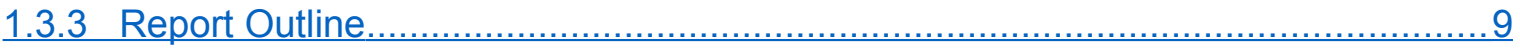

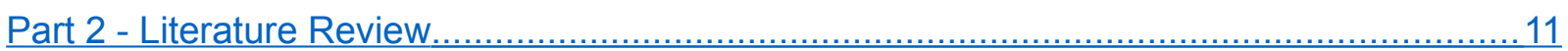

2.1 Key Organizations and Stakeholders............................................................. 11

2.2 Findings from Literature ................................................................................ 12

2.2.1 Benefits of Community Energy Planning ......................................................12

2.2.2 Conditions for Successful Community Energy Planning.....................................14

2.2.3 Municipal Role in Community Energy Planning...............................................16

2.2.4 Community Energy Planning Content................................................................... 19

2.3 Critiques and Limits of Community Energy Planning...............................................19

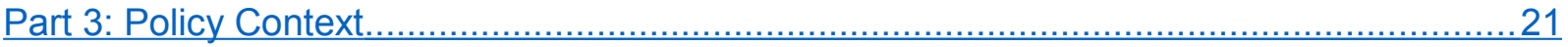

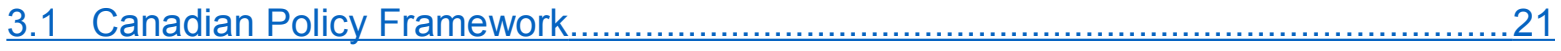

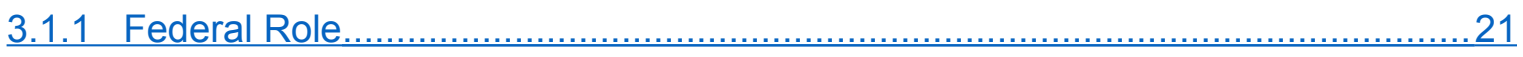

3.1.2 Provincial Role .................................................................................................22

3.1.3 Ontario Provincial Support of Community Energy Planning...............................23

3.1.4 British Columbia Support of Community Energy Planning.................................25

3.2 Role of Local Government and Institutions ...............................................................22

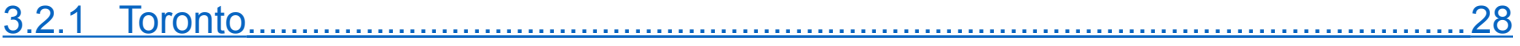

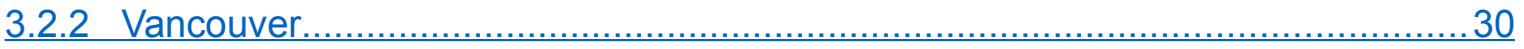

3.2.3 City of North Vancouver............................................................................ 32

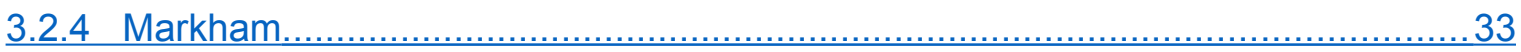

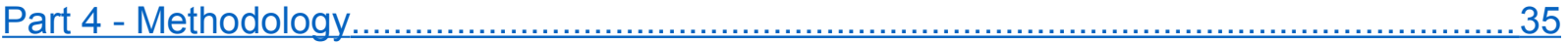

Part 5 - Results and Discussion................................................................................

5.1 General Overview and Conditions........................................................................... 37

5.2 Municipal Roles.............................................................................................. 42

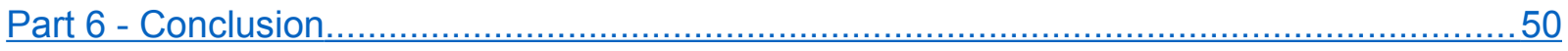

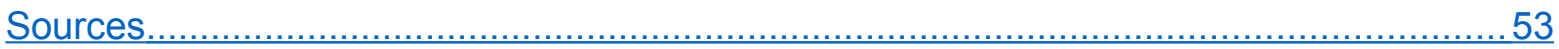

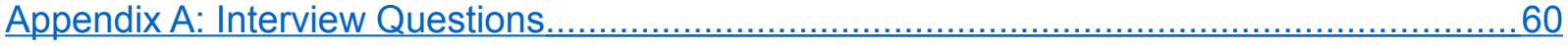




\section{Part 1: Introduction}

\subsection{Research Statement}

This Masters Research Paper (MRP) is an evaluation of Community Energy Plans (CEP) as a tool for municipalities to reach their carbon reduction targets and plan sustainable cities with a high quality of life. It explores the underlying conditions of what motivates municipalities or neighbourhoods to adopt community energy plans. The MRP undertakes a policy comparison analysis of CEPs in four municipalities in Ontario and British Columbia: Toronto, Vancouver, City of North Vancouver, and Markham. All four cities have a history of community energy planning and local environmental planning, whether through specific neighbourhood energy generation projects, or wide-scale strategic municipal energy planning. The MRP determines the key roles that municipalities typically play in the community energy planning process, and evaluates the extent to which each of the municipalities has taken on those roles. The aim is to find similarities and differences in how municipalities define, develop, and implement CEP in Canada.

This is an exploratory paper intended to provide a primer on local energy planning and review what has already been done and what is still to be done in Canadian communities to reduce carbon emissions and strategize resilient, renewable, post-carbon cities.

\subsection{Issue Background}

Canada has committed, under the Paris Agreement, to reducing greenhouse gas (GHG) emissions by 30\% below 2005 levels by 2030 (Environment and Climate Change Canada, 2016a, foreword). Reducing carbon and GHG emissions is the most important part of taking proactive action against climate change and preserving life across the globe. Negative effects of climate change have already been experienced in all of Canada's regions in forms such as wildfires, floods, and erosion (ibid). Immediate and deep action is required to stop and reverse these effects.

GHG emissions are predominantly produced by human activity. A large portion are created when fossil fuels are burned for energy, releasing gasses such as $\mathrm{C0} 2$ into the atmosphere. GHG emissions-producing energy consumption is generally bucketed into the following 
categories: transportation, electricity (including buildings), and the production and provision of goods and services. These activities are central to urban life. In fact, $60 \%$ of energy in Canada is used in cities, and cities produce over $50 \%$ of total GHG emissions (Community Energy Association et al., 2016). It follows that municipalities will inevitably be required to deal with the effects of climate change, both by dealing with the effects, as well as tackling the root of the issue by transforming energy systems to become carbon emissions-free. Proactive, placebased sustainability planning with ambitious carbon reduction goals is beneficial for many reasons. In addition to contributing to the greater global efforts to abate the forces of climate change, it has been seen that reducing the carbon footprint of cities has positive local impacts on the livelihoods of residents (Singh et al., n.d.).

\subsubsection{Approaching the Problem at a Municipal Scale}

There are two approaches that are important to consider in the strategy to reach these climate action goals: demand and supply of energy. Municipalities can play a role in both. Energy demand management is the practice of changing consumer behaviour, technology, and systems to require less energy or use energy more efficiently. The other side of the system, supply management, looks at the source of the energy. This is where renewable energy technology comes into play. Clean, renewable energy sources that do not produce GHG emissions can help Canada to reach its 2030 climate action targets if they are implemented widely. Every unit of fossil fuel that is replaced with renewable, clean energy contributes towards this goal. As new energy technologies are developed and become financially and logistically feasible to implement, it is important to also develop a framework that will enable and encourage public and private adoption. CEPs can help to bridge the gap between technology, research and development, and implementation at a practical scale.

\subsection{Community Energy Planning}

\subsubsection{What are Community Energy Plans?}

Community energy planning is a part of the larger movement of community-based environmental planning (Measham et al, 2011). This practice highlights the importance of municipal action to mitigate and reverse locally-experienced negative impacts of climate change (ibid). A CEP is a vision and action plan that manages energy demand and production to the extent possible within the jurisdiction of a municipality. This type of strategic planning is 
foundational for fostering sustainability at a local level. CEPs integrate the strengths of land use and urban planning with sustainability best practices, implementation of new energy technology, and community involvement. As the City of Toronto puts it, "Community Energy Planning considers energy use early in the land use and infrastructure planning process and identifies opportunities to integrate local, low-carbon, and resilient energy solutions at the building and district-scale" (City of Toronto, Environment \& Energy Division, n.d.).

Many municipalities and neighbourhoods in Canada have begun to implement CEPs. This is part of the global effort to manage energy demand, make deep reductions to GHG emissions, and shift towards clean energy production and technology (Community Energy Association et al, 2016). Natural Resource Canada's Council of Energy Ministers' 2009 report Integrated Community Energy Solutions marks the current time period (2010-2050) as a time for widespread adoption of community energy plans and renewable energy. Currently over $50 \%$ of the population of Canada lives in a community that has undertaken some form of CEP (Community Energy Association, et al., 2016). British Columbia residents are the most covered by a CEP at $79 \%$ of the population, with Ontario coming in 2 nd with $64 \%$ of the population ${ }^{1}$ (ibid).

The difference between a municipality that has a CEP compared to one that doesn't is that the role of the municipality with a CEP has moved from being a role of providing services and infrastructure to a new role as a leader in sustainability, resilience, and innovative climate change action (Singh et al, n.d.). CEPs create an opportunity to highlight municipalities as ambitious, forward-thinking leaders and catalysts for change. An additional benefit of a municipality adopting a CEP is that it may allow the city to set even more ambitious climate action targets than the existing provincial, federal, or international climate commitments.

\subsubsection{What is in a Community Energy Plan?}

CEPs are a culmination of considerations. As seen in this research, not all CEPs look alike or contain comparable goals and actions. The way in which municipalities determine and reach their climate targets varies greatly between cities. There is no formula for how to write a CEP, however, the following broad elements can generally be found among CEPs:

- baseline or inventory of community-wide energy consumption and GHG emissions, 
- solutions and improvements to energy systems with clear actions,

- strategy to generate community and industry support for renewable energy,

- key performance indicators to monitor and measure progress towards targets and outcomes (BC Hydro, 2009; Evensen, Margerm \& McDonough, 2013; Community Energy Association et al, 2016).

CEPs touch on many areas and jurisdictions of planning. They overlap with municipal infrastructure, energy, economic, environmental, and social programs. Ideal CEPs are practical roadmaps with action items tied to principles and goals (Singh et al, n.d.). Additionally, the consideration for land use planning may direct vacant or underutilized municipal land to be used for energy generation or other energy-adjacent uses such as distribution grids (ibid). Finally, CEPs present an opportunity to unify language used between technical and planning professionals, and encourage inter-departmental cooperation (ibid).

Because CEPs are integrative, they tend to highlight benefits to the environment, health and wellbeing, local economic benefits, and general urban resilience. By mobilizing local resources and priorities, CEPs capture additional benefits such as increased air quality, increased social connectivity, improved quality and number of local jobs, increased property values, reduced exposure uncertainty and risk, and more. Many stakeholders can stand to benefit from CEPs including local governments, First Nations, utilities and service providers, property owners, and community members (Community Energy Association et al., 2016.)

\subsubsection{Report Outline}

The remainder of this MRP presents a review of the policy frameworks in Ontario and British Columbia that enable and support community energy planning on a municipal scale. Part 2 presents a review of the literature on the field of community energy planning (particularly in Canada), while Part 3 explores the policy context in which CEPs are created. Parts 4 and 5 present the methodology and the result of an evaluation of the four chosen municipalities and their CEPs, respectively. The case studies chosen are Toronto, Markham, Vancouver, and the City of North Vancouver (refer to Table 1). Within Toronto, Scarborough Centre's CEP was chosen for deeper analysis because it represents a well established, mixed-use community experiencing growth, making it a good example of a neighbourhood that will require detailed energy planning. Conclusions are drawn in Part 6. 
Table 1: City size and population comparison

\begin{tabular}{|l|l|l|l|l|l|}
\hline & $\begin{array}{l}\text { City of North } \\
\text { Vancouver }\end{array}$ & Vancouver & Markham & Toronto & $\begin{array}{l}\text { Scarborough } \\
\text { Centre }\end{array}$ \\
\hline Population (2016) & 52,898 & 631,486 & 328,965 & 2.73 million & 112,603 \\
\hline Area & $11.8 \mathrm{~km}^{2}$ & $115 \mathrm{~km}^{2}$ & $212 \mathrm{~km}^{2}$ & $630 \mathrm{~km}^{2}$ & $28.19 \mathrm{~km}^{2}$ \\
\hline
\end{tabular}

(Census Canada, 2016)

2The CEP examined in Toronto for this research is the CEP for Scarborough Centre, therefore population and size data this neighbourhood are shown for context. 


\section{Part 2 - Literature Review}

Planning for environmental sustainability has been common practice in urban planning theory and implementation for several decades. However, community energy planning is only just becoming commonplace. Literature is currently being published encouraging municipalities to adopt CEPs, while the first critical reviews of CEPs are also making their way through academic and professional circles. This literature review captures a small portion of writing from the general field of municipal climate action efforts, however, it mainly focuses on research specific to CEPs.

\subsection{Key Organizations and Stakeholders}

Key players $\mathrm{n}$ the development of community energy planning are the municipalities themselves, and a network of organizations and agencies with resources to help. CanmetENERGY is the branch of Natural Resource Canada's energy planning and research division, which publishes studies, guides, and best practices for urban energy planning (Natural Resources Canada, n.d.). As a federal agency, CanmetENERGY research is key because they have the authority to inform policies that govern how municipalities and even provinces approach energy and emissions planning.

Utilities also contribute to the conversation with research, best practices, and standards. In British Columbia, BC Hydro has been a proponent of CEP for at least a decade, publishing their case study and best practices research in 2009 (BC Hydro, 2009). In Ontario, the energy market is more fragmented than BC. Some utilities, such as Hydro One have not yet published research or run programs on CEP. However, the Independent Electricity System Operators (IESO) of Ontario run a CEP program specifically targeted to Indigenous communities - the Aboriginal Community Energy Plan Program, as described in the previous section (IESO, n.d.).

A large and broad scope of work has been undertaken by a community of think tanks and nongovernmental groups of sustainability and community leaders. The Community Energy Association is the independent advisor to the BC Energy Council regarding CEP matters in British Columbia (Community Energy Association, n.d.). QUEST is the leading non-profit organization working to integrate community energy projects and programs across Canada (QUEST, n.d.). The group undertakes research and works with all levels of government and industry to reach their goal of every community in Canada becoming a "smart energy" 
community by 2030 (QUEST, n.d.). In addition to specific CEP research, a larger body of research on community-based environmental planning exists, which informs many of the goals and visions of CEP. To name one key document relevant in Canada at this time, the Trottier Energy Future Project, a partnership between the Trottier Institute and the David Suzuki Foundation, informs the discussion (Trottier Energy Futures Project, 2016).

In addition to government and non-governmental organizations, academic circles have also published research pertaining to a variety of topics related to CEP. Ontario's Community Energy Knowledge-Action Partnership is a joint venture of universities across Canada, whose faculty and graduate students undertake research relating to local energy in Canadian municipalities (CEKAP, n.d.). A long-standing academic body that has looked at CEP is the University of Toronto's Sustainable Infrastructure Group, who published a report in 2009 called "Getting to Carbon neutral: A Guide for Canadian Municipalities" (University of Toronto Sustainable Infrastructure Group, 2009). Lastly, the topic of CEP is popular among sustainability think-tanks. The Sustainable Prosperity Institute, Ryerson University's Centre for Urban Energy, and the Neptis Foundation have all contributed to the discussion through publishing white papers or contributing to research.

\subsection{Findings from Literature}

\subsubsection{Benefits of Community Energy Planning}

In terms of defining and listing the benefits of CEP, the results across all literature were straightforward and uniform. CEP is a tool to evaluate urban GHG emissions in a systematic and action-oriented manner, which is important for reaching climate action targets (Karunathilake et al, 2018). The three elements of sustainable energy systems found across the literature were efficiency, conservation, and carbon-free energy sources (ibid). Finally, the general body of literature on distributed electrical grids and energy generation alluded to three general categories of benefits: environmental, social, and economic. Below is a list of findings from the literature on these topics.

\section{Environmental Benefits}

- $\quad$ CEP creates opportunities to integrate renewable energy (Karunathilake et al, 2018; QUEST, 2016; Singh et al, n.d.; Tozer, 2013; BC Hydro, 2009). 
- $\quad$ CEP is a way to achieve deep energy and greenhouse gas emissions (CEA, 2016; Evanson et al, 2016; QUEST, 2016, Singh et al, n.d.; BC Hydro, 2009).

\section{Social Benefits}

- $\quad$ CEPs allow for a greater level of comfort for all residents due to the increased efficiency and reliability of energy service, and reduced cost (CEA, 2016; Evenson et al, 2016; QUEST, 2016, Singh et al, n.d.).

- $\quad$ CEPs can increase social connectivity as neighbourhoods work together in the participatory CEP process (CEA, 2016; Tozer, 2013; QUEST, 2016, Singh et al, n.d.).

- $\quad$ CEPs can result in increased air quality, which brings about an entire set of health benefits to the local community (CEA, 2016; Tozer, 2013; QUEST, 2016; Singh et al, n.d.).

- $\quad$ Community resilience to climate change, such as power outage events and grid failures, are reduced due to CEP (CEA, 2016; QUEST, 2016; Singh et al, n.d.).

- Local residents are empowered to make decisions, decide priorities, and take control of their own carbon footprints (CUE, n.d.; CEA, 2016; Evenson et al, 2016; Tozer, 2013; QUEST, 2016, Singh et al, n.d.).

\section{Economic Benefits}

- $\quad$ CEP creates opportunities for local stakeholders to invest into the energy market (Krunathilake et al, 2018, Community Energy Association, et al, 2016; Evenson et al, 2016; QUEST, 2016; Singh et al, n.d.; BC Hydro, 2009).

- $\quad$ CEP keeps the economic benefits of energy generation local, and benefits local consumers, businesses, and governments (Community Energy Association, et al, 2016, CUE, n.d.; QUEST, 2016; Singh et al, n.d.; BC Hydro, 2009).

- $\quad$ High-quality jobs are created through CEP projects (Community Energy Association, et al, 2016; Tozer, 2013; QUEST, 2016; Singh et al, n.d.).

- $\quad$ Property values can increase because of integrated energy systems and efficient buildings (Community Energy Association, et al, 2016). 
- Rate-payers save money on energy costs due to increased efficiency, conservation, and predictable market (Tozer, 2013; QUEST, 2016).

\subsubsection{Conditions for Successful Community Energy Planning}

The majority of studies and literature reviewed found similar and overlapping results when examining CEP. This includes similar incentives, barriers, and recommendations from multiple studies across Canada done at different times. It should be noted that certain conditions are planning issues, in which the ideal circumstances can be created through well-designed policy and programs. However, some conditions are technical issues, which fall outside of the scope of this research.

Table 2 represents a cross-section of the general factors of success or barriers at the municipal level for CEP determined across five studies over the past 10 years. Not all conditions listed in every article are present, but the overlapping and recurring themes are noted. These recurring themes will be used in the next section to compare to selected case study CEPs. In this instance, "success" is determined by the CEP process being undertaken, and adoption of a plan within the municipality. 
Table 2: Matrix of Conditions/Context for Successful CEP across research.

\begin{tabular}{|c|c|c|c|c|c|c|}
\hline & \multicolumn{6}{|c|}{ Studies/Reports } \\
\hline & 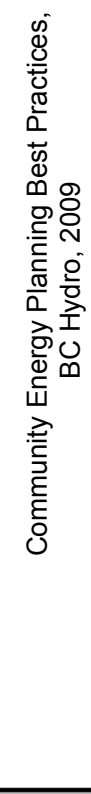 & 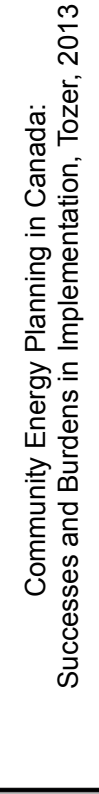 & 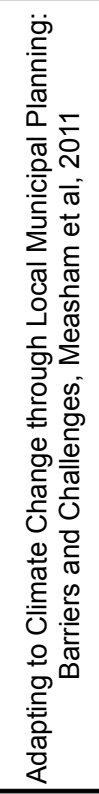 & 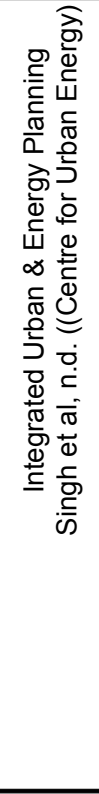 & 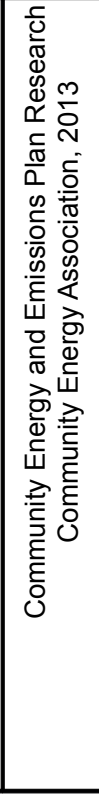 & 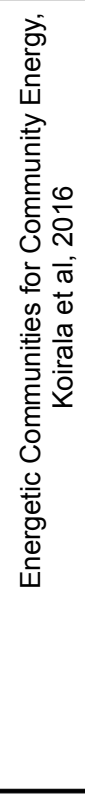 \\
\hline \multicolumn{7}{|l|}{ Common conditions and features for successful CEPs } \\
\hline $\begin{array}{l}\text { Commitment (at some level of government) to climate change } \\
\text { action \& GHG reduction }\end{array}$ & $\checkmark$ & $\bar{\jmath}$ & & $\bar{T}$ & & $\checkmark$ \\
\hline $\begin{array}{l}\text { CEP is integrated into a broader, holistic sustainable urban land } \\
\text { use system (ie. transportation, infrastructure) }\end{array}$ & $\sqrt{ }$ & $\bar{\checkmark}$ & $\sqrt{ }$ & $\bar{T}$ & $\checkmark$ & $\checkmark$ \\
\hline Other policies (Official Plan, growth plans, etc.) support CEP & $\checkmark$ & $\checkmark$ & & $\bar{T}$ & $\checkmark$ & $\checkmark$ \\
\hline Staff \& politicians show strong leadership and champion CEP & $\checkmark$ & $\checkmark$ & $\checkmark$ & 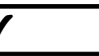 & $\sqrt{ }$ & $\checkmark$ \\
\hline $\begin{array}{l}\text { Communities and stakeholders are educated, informed, and } \\
\text { involved in participatory planning }\end{array}$ & $\checkmark$ & $\checkmark$ & $\sqrt{ }$ & r & & $\sqrt{ }$ \\
\hline Barriers of successful CEPs & & & & & & \\
\hline Jurisdiction or authority of local government & $\checkmark$ & $\checkmark$ & $\sqrt{ }$ & & $\checkmark$ & $\sqrt{ }$ \\
\hline Cost, lack of financing, or other financial priorities & & $\sqrt{ }$ & & & $\checkmark$ & $\checkmark$ \\
\hline Capacity/experience of staff & $\bar{Q}$ & $\sqrt{ }$ & $\bar{\checkmark}$ & & $\checkmark$ & \\
\hline
\end{tabular}




\subsubsection{Municipal Role in Community Energy Planning}

Existing literature has explored the role of municipal governments in energy management. The following five key roles were identified in the body of mostly Canadian-specific literature on CEP. This list is not exhaustive but represents the most common and overlapping indications of the municipal role in CEP across the general body of literature.

1. Plan integrated, sustainable cities.

Energy management as part of a broader strategy of greening cities is an impossibly vast topic to cover. CEP represents only a small subset of sustainability. However, many articles begin by noting that a CEP is a tool that only works within a broad system of holistic sustainability. BC Hydro's 2009 best practices report reviewed ten international case studies and noted characteristics of mixed-use land use, density, transit-oriented planning, strong leadership and community engagement in all cases (BC Hydro, 2009). Similarly, QUEST \& the Community Energy Association's 2016 Community Energy Planning: Getting to Implementation in Canada report details that CEP is part of an integrated system of energy, land use, transportation, and waste (Community Energy Association, 2016).

The Natural Resources Canada Council of Energy Ministers' 2009 report Integrated Community Energy Solutions gives away in its title that CEP is part of a city-wide planning exercise ${ }^{3}$. The report begins by stating that climate change solutions should capitalize on local synergies by "integrating multiple sectors, including energy supply and distribution; transportation; housing and buildings; industry; water, waste management, and other local community services; and land use and community form" (p. 1).

2. Turn plans and visions into action.

Several papers pointed to the local government level as the driver of implementation and action. Ryerson University's Centre for Urban Energy's report outlined the role of municipalities to integrate energy policy into infrastructure and the built environment, urban development guidelines, and technical specifications to ensure implementation in the planning process (Singh et al, n.d.). Similarly, the implementation of CEP through other actionable items includes zoning,

3Although Koirala et al's report 2016 report Energetic communities for community energy: A review of key issues and trends shaping integrated community energy systems also implies integration in planning, the term "integrated community energy system" in this study moreso refers to the integration of the energy grid and system, not planning necessarily. 
official plans, growth plans, and use of municipal lands (Tozer, 2013; Singh, et al., n.d.;

Community Energy Association, 2013;). These tools all represent ways that the municipality can use to ensure the conditions are favourable and barriers are avoided so that the CEP is set up for success. Karunathilake et al also state that strategic energy planning should be a requirement of the development approval process of upcoming neighbourhoods (2018).

Measham et al's 2011 report Adapting to climate change through local municipal planning: Barriers and challenges does not specifically refer to CEP, but its emphasis on the municipality's role to turn plans into climate action bears weight here as well. Measham et al point to the role of the city council as the implementer of all levels of government policies. However, contradictorily, the role of council and city staff was also found to be a mediator between higher levels of government, sometimes to a point where it actually stalled implementation of climate action (Measham et al, 2011).

\section{Empower the community and stakeholders.}

A common theme of reviews and studies was meaningful engagement, partnerships, and involvement (Singh et al., n.d.). This means that the successful CEPs were not implemented from a top-down approach, but rather sought out and catered to the needs of stakeholders and residents. This requires education and empowerment of the community. The demands and vision of the public were seen to be a driver for ensuring that city councils direct plans into actions. This is particularly seen when users demand features such as better reliability of power supply, stable pricing, greater options, and more control over the design and implementation of energy projects (Singh et al, n.d.). Tozer found in 2013 that the role of local government is partially as a champion for the various stakeholders and community to align goals and achieve implementation together.

In Koirala et al's 2016 report on CEP in Europe, Energetic communities for community energy: A review of key issues and trends shaping integrated community energy systems, community engagement is deemed essential in implementing CEP and receiving the full potential benefits. The role of the municipality is also identified to trust and support community-led initiatives such as energy trusts (Koirala et al, 2016). BC Hydro's 2009 case study review pointed to Guelph's unanimous council support of its CEP as a success. This is because the level of civic and political support at the beginning planning stages allowed the City to enact all the measures necessary to turn the CEP from being a plan to becoming a reality. The same case study also 
pointed to the fact that a high level of community support, in turn, led to support from financial investors. This support was based on participatory planning, and including civic groups through formal meetings, briefings, and ensuring that residents shared an understanding of the goals, challenges, and benefits of the CEP (BC Hydro, 2009).

\section{Highlight local benefits and value.}

The burden to prove the benefits to the community lies on the municipality. Measham et al's 2011 research found that the key role of local government was to create value and benefit to the local residents through place-based climate action. This paramount role simultaneously manages climate change adaptation and resiliency, while providing local improvements. Within CEP, this includes ensuring the delivery of the benefits noted in the previous section, while additionally reaching climate targets nationally and regionally. Tozer found in 2013 that the role of municipalities was to implement CEP by emphasizing the secondary benefits, including employment.

As discussed in Koirala et al, 2016, the interest of the community and the local government found similar results. This included a municipal-level government's role to ensure that the interests of residents were met, including affordable energy, resiliency to climate change, and availability of local, clean energy with the possibility for resale profits (Koirala et al, 2016).

\section{Campaign for greater support of CEP in all levels of government.}

To create successful CEP, a great deal of authority and finance must be available at the local level. Koirala et al determine that a role of local government is to lobby for increased government support, self-governance authority, and financial incentives to implement CEP (2016). The uneven relationship between local and higher levels of government forces cities to either be constrained in their powers or engage with the broader governance network to create institutional arrangements that allow them to undertake appropriate measures (Measham et al, p. 892). As the paper found, "councils frequently fulfil the role of implementing actions defined at higher scales, with little room to manoeuvre. Therefore, a lack of attention to climate change at the national and state levels leads to a lack of attention to climate adaptation at the local level" (ibid, p. 905). BC Hydro's case study of Guelph's early CEP success also pointed to the city's leadership in engaging the provincial and federal government bodies (BC Hydro, 2009). 


\subsubsection{Community Energy Planning Content}

The common content of CEPs was also examined through a literature review. A report from a 2013 study undertaken by Natural Resources Canada compared 30 Community Energy and Emissions Plans in Canada from 2004-2013 (Community Energy Association, 2013). The study noted a high level of consistency in content among the plans when considered at a high level. They all included a variety of targets, measurements, and actions. They all also operated within the three elements of CEP; energy efficiency, conservation, and reducing greenhouse gas emissions through renewable energy generation (Community Energy Association, 2013; Tozer, 2013). The study also noted that almost all CEP or energy management strategies were only one part of a larger sustainability framework within the municipality.

The Community Energy Association, QUEST, and Sustainable Prosperity (now known as the Smart Prosperity Institute) joined together to write the pre-budget submission to the 2016 House of Commons Standing Committee on Finance (Community Energy Association, et al, 2016). This report describes a typical CEP as containing energy or emissions targets, action to achieve those targets, key performance indicators to monitor advancements, and an evaluation. This is a fairly standardized approach to most plans. Similarly, the Centre for Urban Energy's white paper on the matter outlined only that CEPs should be practical planning documents that contain specific actions and programs (Singh et al, n.d.). Natural Resources Canada's 2013 comparative study noted that successful CEPs monitored and tracked implementation actions and progress (Community Energy Association, 2013). The scan also recommended specific and clear next steps in CEPs (ibid).

\subsection{Critiques and Limits of Community Energy Planning}

It is necessary to also address some criticisms and shortcomings of CEP found in the literature. As the industry is growing and changing, some studies have pointed out areas in which CEP can greatly improve or has not fulfilled what it set out to do. For example, in Tozer 2013, it was noted that while reductions were made in GHG emissions produced by municipal operations in the cities examined, the overall GHG emissions were not significantly reduced. This does not necessarily follow that long-term municipal GHG emission levels will never be reduced, but at the time of the study, the data had not shown this to be the case (ibid). Similarly, Karunathilake et al found in 2018 that an increased percentage of renewable energy in a community's energy source mix did not directly correlate to lower GHG emissions or lifecycle costs for that community. The study stresses the importance of modelling a variety of combinations and 
emphasizes that the differences of each scenario, community, and circumstance play an undeniable role, so tailoring CEPs is of utmost importance (ibid).

On the topic of deep GHG emissions cuts, the 2009 BC Hydro Community Energy Planning Best Practices report found that municipalities with holistic approaches to GHG emissions, including efficient transportation, efficient use of fuel, integrated energy supply, and world-class efficiency, such as Copenhagen, resulted in far fewer tonnes of GHG per capita than the average Canadian city (BC Hydro, 2009). It's possible that even today, there are simply no Canadian cities with an integrated, efficient, and holistic energy and environmental planning as European cities, with up to four times lower GHG emissions total than the Canadian average, according to the decade-old study (BC Hydro, 2009).

Most recently, a July 2018 MRP from York University's Susan Wyse took a critical approach to the extent to which the community is actually involved in CEP (Wyse, 2018). This research finds that, although certain benefits such as energy efficiency are found to be reached in a study of Canadian CEPs, not all social benefits necessarily occur as they are portrayed in literature and plans (ibid). The MRP points also to the greater issue that CEP is chronically understudied in Canada, and requires more broad and in-depth studies to truly understand the impacts and benefits (and distribution thereof) of CEP. On the same topic, in September 2018 the US-based Urban Sustainability Directors Network published A Guidebook on Equitable Clean Energy Program Design for Local Governments and Partners. This guide provides guiding principles and practical steps to ensure that CEP projects are undertaken in an equitable manner, focusing in the process of CEP, not solely the outcomes (Urban Sustainability Directors Network, 2018). 


\section{Part 3: Policy Context}

\subsection{Canadian Policy Framework}

Federal, provincial, and municipal policies have been implemented to help Canada reach its targets for carbon emission reduction. There has been an evolving nature of climate change policies in Canada as governments change and new plans are forged, but the trend generally is for federal and provincial governments to set overall targets and provide some funding, while local governments must conform their own policies and plans accordingly. Regulation with regards to energy varies, however. Generation, transmission, and distribution - the components of energy systems - are generally under the jurisdiction of the province. Municipalities face jurisdictional challenges in making transformative changes in any of these areas.

\subsubsection{Federal Role}

The federal government has led the way forward for climate change action in Canada. In March 2016, leaders from across Canada met in Vancouver, where the First Ministers published the Vancouver Declaration on Clean Growth and Climate Change, which includes the climate commitments that make up the foundation of the Pan-Canadian Framework on Clean Growth and Climate Change (Canada's First Ministers, 2016). The Pan-Canadian Framework is tied to the 2015 Paris Agreement, made as part of the United Nations Framework Convention on Climate Change (Environment and Climate Change Canada, 2016a). Although these high-level, nationwide policies are in place, Canadian municipalities are major consumers of energy, they will play a vital role in the reduction of GHG emissions in Canada, and in meeting the Paris Agreement 2030 goals.

The Pan-Canadian Framework on Clean Growth and Climate Change, and its accompanying action plan, Federal Actions for a Clean Growth Economy both support the principles of community energy planning but have no direct mention of municipal action (Environment and Climate Change Canada, 2016a, b). However, municipalities are eligible to apply directly for grants available through the Low Carbon Economy Fund ${ }^{4}$ to enable local projects and plans that

4The Low Carbon Economy Fund is a \$2B resource, funded by the Federal Carbon Pricing scheme, dedicated to reducing greenhouse gas emissions and growing Canada's clean growth economy. It is divided into two sections - the Low Carbon Economy Leadership Fund is only available to provinces and territories; the Low Carbon Economy Challenge is competition-style challenge in which municipalities are eligible to make a submission. (Environment \& Climate Change Canada, n.d.) 
contribute towards the targets of the "clean growth economy" (Environment and Climate Change Canada, n.d.). The federal policies and action plans do not indicate that community energy plans in particular are necessary, but rather encourage high-level principles and widesweeping areas of action. Although municipalities may choose any tool they see fit to meet the targets and requirements set by federal policies, CEPs are an ideal tool because it meets local and federal requirements.

\subsubsection{Provincial Role}

Before examining how, and to what degree provinces can support local energy planning, it is essential to examine provincial control of municipal powers in general. As the degree of autonomy of municipalities is determined by the province, it varies across Canada from province to province. British Columbia and Ontario are the two provinces examined in this research, and they distribute power with the following tools.

In Ontario, the Planning Act, 1990 and the City of Toronto Act, 2006 are the two key documents that give any administrative powers to municipalities. The acts both grant municipalities power to administer land use planning systems and tools, including Official Plans and Zoning By-laws, and manage finances (Planning Act, 1990). Similarly, in British Columbia, the Community Charter, 2003 and the Vancouver Charter, 1953 distribute administrative rights and responsibilities to municipalities. These documents give broad planning and administrative authority to the municipalities to decide their own priorities and govern themselves to a degree. Both Vancouver and Toronto have additional legal authorities that smaller municipalities in their respective provinces do not because of their special status given by the City of Toronto Act, 2006, and the Vancouver Charter, 1953. These powers include additional taxation and administration priviledges, which can be a major advantage for developing, financing, and implementing new programs and policies. Ontario's Planning Act functions as a list of allowances that the province permits, whereas BC's Bill of Rights approach is more flexible to change and adapt over time (Planning Act, 1990; City of Toronto Solicitor General, 2001). This difference may have an impact when comparing the ambition, feasibility, and implementation of CEPs.

5Clean Growth Economy is the term used in the Pan-Canadian Framework on Clean Growth and Climate Change, it is generally referring to a prosperous, low-carbon future. 
Within the bounds of local government authority, in both BC and Ontario municipalities have the authority to engage in community energy planning. However, the degree of policy intervention from the province varies between BC, Ontario, and among the rest of Canada's provinces and territories. Simply enabling municipalities to take on energy and emissions planning is a minimum expectation and baseline. However, some policies support, require, and even incentivize municipalities to undertake this work (QUEST, 2016). Fortunately, over the past 10 years both $\mathrm{BC}$ and Ontario have made efforts through plans, programs, and policies to engage communities in climate action and clean energy implementation. The Environmental Commissioner of Ontario ${ }^{6}$ emphasizes in its 2018 Greenhouse Gas Progress Report that local governments should not be forced to act alone and that they benefit from strong leadership and examples set at the provincial level (Environmental Commissioner of Ontario, 2018).

Additionally, the Commissioner's office goes on to say that clear policy direction can help municipalities work together towards common climate action goals (ibid). According to data gathered by Quality Urban Energy Systems of Tomorrow (QUEST), the adoption of CEPs in municipalities correlates to the availability of CEP-supporting provincial policies and programs. The study revealed that with each additional provincial policy intervention, new municipalities adopted a CEP (QUEST, 2016). Unfortunately, the timing of the study did not cover a period when policies and programs were cut or reversed, so data observing the opposite trend if adoption of CEPs declines when programs are removed does not exist at this time. The provincial policies that support the transition to carbon-free energy systems through local planning are discussed below.

\subsubsection{Ontario Provincial Support of Community Energy Planning}

Ontario has three policies that directly encourage CEP currently:

1) the Municipal Energy Program,

1) the Aboriginal Community Energy Plan Program, and

2) O-Reg 507/18: Energy Conservation and Demand Management Plans (Ministry of Energy, Northern Development, and Mines, 2013; Electricity Act, 1998).

The voluntary provincial Municipal Energy Plan Program and Aboriginal Community Energy Plan Program provide funding for an initial energy study and to support the CEP in its early stages (Ministry of Energy, Northern Development, and Mines, 2013). The aim of the program is 
to encourage municipalities to take proactive steps towards meeting the targets of provincial environment plans, most recently as of this MRP, the Preserving and Protecting our Environment for Future Generations: A Made-in-Ontario Plan and Ontario's Long Term Energy Plan 2017: Delivering Fairness and Choice (Ministry of Environment, Conservation, and Parks, 2018a; Ministry of Energy, 2017). The province has also partnered with third-party Independent Energy System Operators to administer additional programs and funding to municipalities. Though focused on broad provincial action plan targets, this presents an opportunity for municipalities to tailor the implementation of the action plan to the needs of their communities, and alleviate a portion of the upfront financial burden of doing so.

\section{O-Reg 507/18 Broader Public Sector: Reporting and Conservation and Demand Management} Plans (formerly O-Reg 387/11 under the now repealed Green Energy Act, 2009) is the provincial requirement for municipalities and other public agencies to prepare and implement energy conservation and demand management plans (Electricity Act, 1998; Green Energy Act, 2009). This reporting requirement is the only mandatory policy in Ontario at this time. Although this policy does not necessarily have to be interpreted as the creation of a CEP, this inventory and reporting mechanism is certainly a helpful data source and municipal exercise on which to base a CEP.

The objective of these three policies is to conserve energy, and inventory and reduce GHG emissions. The policies don't directly support decentralized energy systems or local generation, ad only require any that exist are inventoried. Some financial incentives are supplied through the Municipal Energy Program and Aboriginal Community Energy Plan Program. However, these policies call for low levels of provincial support and leave ample room for program expansion and improvement. Improvements could include: mandatory participation; additional resources and capacity-building for municipalities; and further financial offerings.

In Ontario, the rate of adopting CEPs has been steadily increasing over the past decade (QUEST, 2016). In 2011, when O-Reg 397/11 was implemented, there were 14 complete CEPs in the province (ibid). In 2013, when the Municipal Energy Program and Aboriginal Community Energy Plan Program were implemented, there were 18 complete CEPs in the province (ibid). As of 2016, 97 CEPs have been developed in Ontario (ibid). In other words, the rate of communities that adopted a CEP increased by $592 \%$ between $2011-2016$. As of $2016^{7}$, the 
Ministry of Energy reported that 18 municipalities in Ontario have participated in the Municipal Energy Plan Program (Ministry of Energy, 2016). The discrepancy between the numbers reported by QUEST and the Province of Ontario are due to reporting differences, and due to the fact that many of the CEPs recorded by QUEST were funded by the Aboriginal Community Energy Plan Program, which was not counted in the Ministry of Energy's count (Lee, 2019).

Finally, in 2018 Ontario cancelled its carbon pricing scheme, repealing the Green Energy Act altogether (Ontario News, 2018). It is outside the scope of this MRP to explore the full effect of the program cancellation, and may even be too early to see the full impact. However, it is worth noting that this program was the only offering by the Province of Ontario that was specifically designed to expand renewable energy production and grow the green economy. The Ontario Green Energy Fund, funded by cap and trade carbon pricing, was intended to contribute $\$ 1.9$ billion dollars per year across Ontario to fund carbon emissions reduction efforts (Environmental Commissioner of Ontario, 2018; Ministry of the Environment, Conservation and Parks, 2018b). Without the proceeds from this program, Ontario municipalities that relied on the program for funds must find other funding sources or face shortfalls in their climate action budget and programming. As stated in the Ontario Environmental Commissioner's 2018 Greenhouse Gas Progress Report, "if Bill 4 passes as is, Ontario will have no statutory emission targets, no pathway to achieve meaningful targets, weak reporting, no financial incentive for climate polluters to reduce their emissions, and no dedicated source of funding to invest in solutions" (Environmental Commissioner of Ontario, 2018, p. 69).

\subsubsection{British Columbia Support of Community Energy Planning}

$\mathrm{BC}$ offers a strong support for local climate action through climate policies and energy policies, as outlined in the Clean BC Report, BC Climate Leadership Plan, Bill 27, also known as the Green Communities Act, 2009, and the BC Energy Plan (Clean BC, 2018; Province of British Columbia, 2016; Ministry of Energy, Mines, and Petroleum Resources, 2007). For example, the BC Climate Action Toolkit is a resource set up entirely to help organizations such as municipalities undertake sustainability measures (Climate Action Toolkit, n.d.). The toolkit offers step-by-step instructions and guidance for writing a CEP, and offers resources to help. The toolkit is offered by a joint partnership between the province, the union of BC municipalities, and non-profit society the Fraser Basin Council (Climate Action Toolkit, n.d.).

8Bill 4, Cap and Trade Cancellation Act, 2018, passed December 4, 2018 (Bill 4, 2018). 
The policies and programs offered by the Province of British Columbia include:

- the Local Government Climate Action Charter, 2007,

- Climate Action Revenue Incentive Program,

- Clean BC Communities Fund,

- the Green Communities Act, 2009, and,

- Community Energy \& Emissions Inventory.

BC's Local Government Climate Action Charter is a voluntary commitment, though 187 of BC's 190 communities have signed on (Province of British Columbia, n.d.a). The charter outlines the responsibility of local governments to plan livable, sustainable communities, including the production of clean energy as an action item. Communities who have signed onto the charter are eligible for funding from the Climate Action Revenue Incentive Program, essentially a carbon tax rebate to incentivize local governments to take on the work of carbon reductions (Ministry of Municipal Affairs and Housing, 2018).

The Clean BC Community Fund is a joint collaboration between the Ministry of Municipal Affairs and Housing, and the Ministry of Environment and Climate Change. This program shares the costs of projects focused on renewable energy, clean energy transportation, improved energy efficiency of buildings, and the generation of local clean energy (Clean BC, 2018).

The Green Communities Act, 2009 requires municipalities to set targets, policies, and actions in their Official Plans and regional Growth Strategies and gives municipalities increased authority to finance these plans, including through the use of development charges, cash-in-lieu funds from development agreements, and more.

The Community Energy \& Emissions Inventory is the most impactful and engaged of all policies in BC or Ontario. It goes beyond laying out policies and principles and actually provides data for municipalities to use in their CEPs (Province of British Columbia, n.d.b). This proactive strategy alleviates some of the resources and capacity burdened on municipalities. It allows CEP to become more feasible among the competing priorities of the municipality by moving a portion of the work and cost of CEP development to the province. 
Overall, the adoption of CEP is extremely high in BC, likely due to the amount of support, funding, and provision of data from the province. The most significant jump in adoption of CEP was after 2010, when the Community Energy \& Emissions Inventory, and Climate Action Revenue Incentive Programs began (QUEST, 2016). The year prior in 2009, 19 municipalities in BC had adopted CEPs (ibid). As of 2016, 124 communities in BC have implemented CEPs, an increase of $553 \%$ in seven years (ibid).

In order to make CEP possible, at the very least provinces must allow municipalities the authority to write and implement their own CEP. This includes the authority to control and create decentralized energy systems and jurisdiction to require that urban systems meet a high standard of energy efficiency and carbon reduction. In some cases, it may also require that provinces allow municipalities to become utilities themselves by producing energy in local generation plants and distributing it to residents with a city-owned energy corporation or branch of local government.

\subsection{Role of Local Government and Institutions}

As previously stated, it is important for climate action to occur locally because its impacts are felt locally (Measham et al, 2011; Environmental Commissioner of Ontario, 2018). This is also known as a place-based approach. The role of local institutions with regards to climate change is to respond to these local impacts, involve the community collectively by informing and engaging, and delivering resources to facilitate climate adaptation (Measham et al, 2011). The responsibilities of municipal governments cover a large territory with regards to climate change action. Regulating the built environment, conservation of natural urban areas such as waterfronts, forests and rivers, requiring standards for building efficiency, and all matters regarding land use planning are already within the toolbox of urban planners in Canada. This section will go into detail on existing policies in place in the four cities chosen for comparison in this MRP.

With this overview of the relationship between provincial and municipal authority, it is possible to now look specifically at the province's role within community energy planning. Within the bounds of these authority-granting acts and laws, municipalities must plan and operate within their jurisdiction, while also meeting overarching provincial plans and policies. Provincial policies such as growth targets or economic plans may create incentives or barriers to local energy planning. It is outside of the scope of this MRP to review all of both province's policies. However, 
policies directly relating to energy are reviewed below. When it comes to CEP, the level of autonomy and jurisdiction given by the province to municipalities directly impacts the scope, scale, targets, and actions possible. It is imperative for municipal CEPs to conform to all provincial policies, but provincial policies do not require any recognition of municipal plans. Unlike federal programs and policies, certain provincial government offerings directly address and support local community energy planning in BC and Ontario.

The four cities to be examined are Vancouver, City of North Vancouver, Toronto, and Markham. Toronto and Vancouver are both the economic and population centers of their respective provinces. Markham and City of North Vancouver are adjacent suburbs to Toronto and Vancouver, respectively, each with their own unique economies, geographies, and demographics.

The following policy overview is an inventory of Official Plan policies and supplementary municipal plans that support CEP in each community.

\subsubsection{Toronto}

City of Toronto Official Plan

The City of Toronto's Official Plan promotes a dense, efficient urban structure that will lead to a smaller ecological footprint (City of Toronto, 2015).

The following tools are provided in Toronto's Official Plan to promote local energy planning at the municipal and local level:

- Avenue Studies, used to develop Mixed Use Areas, support sustainable urban design and allow for efficient, renewable energy systems, as outlined in Section 2.2.3.

- Neighbourhood-designated areas are required to apply sustainable urban systems, including energy, as outlined in Section 2.3.1.

- Natural and built environment policies direct that buildings and infrastructure are to be designed, constructed, and retrofitted to incorporate renewable urban energy generation, co-generation, and other sustainability GHG reduction measures that transition off of carbon-based fuel, as outlined in Section 3.4. 
- Economic competitiveness, energy security, and reliability are vital to employment and economic prosperity and quality of life, as outlined in Section 5.3.4.

- Height and/or density bonus funds collected may be used towards sustainable energy strategies, as outlined in Section 5.1.1.

- Site Plan Control may be used as an implementation tool for energy efficiency, sustainability measures, and greenhouse gas emissions reduction by the city, as outlined in Section 5.1.3.

- Senior government leaders and advocates will advocate for investment and implementation of green energy strategies, as outlined in Section 5.3.4.

Additionally, the Official Plan advocates for sustainable urban systems on all levels, including transportation and travel policies, built environment policies, sustainable design guidelines, density targets, and natural environment protection policies. The Official Plan also requires the development of a municipal energy strategy, to "reduce energy consumption and promote sustainable energy sources" (City of Toronto, 2015, p. 5-14).

\section{TransformTO}

TransformTO is Toronto's climate action strategy, which provides further detail on the sustainability principles in the Official Plan. It was unanimously approved by Council in July 2017 (City of Toronto, 2017b). The strategy calls for efficient use of energy through highly localized shared energy services, transportation, infrastructure, and built form (ibid). It also calls for municipally-led, broad-based behaviour change to achieve the ambitious goals of reducing carbon emissions, based on 1990 levels, $30 \%$ by 2020 ; $65 \%$ by 2030 ; and $80 \%$ by 2050 (ibid).

According to TransformTO, "the City of Toronto has a community energy planning (CEP) program, which is focused on considering energy early in the land-use and infrastructure planning process for an area and identifying opportunities to integrate local energy solutions at the building and neighbourhood-scale. This program focuses on developing low-carbon thermal energy and electricity generation solutions at the building and neighbourhood-scale, alleviating constraints in energy infrastructure through conservation and local sources of low-carbon energy, energy resilience and local economic benefit" (City of Toronto, 2017b, p. 33). In the 
2017 City of Toronto Staff Report that recommended adopting TransformTO, advancing CEP was the top priority listed, with $\$ 430,000$ in operating costs set aside for CEP preparation and implementation (City of Toronto, Climate, Energy \& Resilience, 2017). It was also recommended that CEPs should explore net-zero targets, whenever possible (ibid).

\section{Toronto Green Standard}

A detailed list of performance metrics, action items, and standards can be found in the Toronto Green Standard (TGS), which acts as an implementation action plan for TransformTO and the Official Plan (Acting Chief Planner and Executive Director, City Planning Division, 2017). The TGS is the sustainability requirement for new private and city-owned developments (City of Toronto, 2018). The priorities of the TGS are to improve air quality, reduce urban heat island effect, decrease energy use and GHG emissions from new buildings, make buildings more resilient during power outages, encourage district energy and renewable energy generation, and a variety of other measures (ibid).

The TGS is split into categories in terms of building height (low and high-rise) as well as residential and non-residential. It is also split into tiers for each category, from mandatory requirements to additional voluntary standards, which offer financial incentives such as development charge rebates. The city's Zero-Emissions Buildings Framework also fall under the TGS (City of Toronto, City Planning Division, 2017).

\subsubsection{Vancouver}

Metro Vancouver Integrated Air Quality + Greenhouse Gas Management Plan

The Metropolitan Region of Vancouver, the upper-tier municipality that encompasses the municipalities surrounding Vancouver, carries out planning and visioning for the region. In its 2011 Integrated Air Quality + Greenhouse Gas Management Plan, there is no specific mention of CEPs or local energy projects (Metro Vancouver, 2011). The plan's role is to help facilitate the provincial BC Energy Plan's goals of renewable energy and reduced greenhouse gas emissions (Ministry of Energy, Mines, and Petroleum Resources, 2007). The plan also details that generating clean energy is preferable to polluting first, then planning a "clean up" or "recovery" at a later time. The plan commits to undertaking a regional review of energy and working with municipalities to promote low-carbon energy systems (ibid). It promotes the principles of CEP and commits to providing direct support to local governments through policy and technical 
assistance (ibid). This plan also applies to the City of North Vancouver, which also falls under the jurisdiction of the Metropolitan Region of Vancouver.

\section{Official Plan}

As a Charter City, Vancouver is not required to have an Official Plan, and therefore does not (Vancouver Charter, 1953). Where in Toronto, the Official Plan sets the vision of the city and policies are written to support that vision, Vancouver is not bound by this structure.

\section{Greenest City Action Plan 2015-2020}

Vancouver's Greenest City Action Plan 2015-2020 doesn't directly mention CEP, but the first area of the plan is dedicated towards climate and renewable energy, with the same targets as the Renewable City Strategy. Priority Action 1.2 of the plan is to work with partners to develop new neighbourhood energy systems (City of Vancouver, 2015a).

\section{Renewable City Strategy}

Vancouver's Renewable City Strategy is the visionary document and planning guide to reach its targets of $100 \%$ renewable energy by 2050 and reduction of GHG levels by at least $80 \%$ below 2007 levels by 2050 (City of Vancouver, 2015b). The reasons for developing the strategy are resiliency, economic strength, and a healthy city. The three-part strategic approach is to reduce energy usage, increase demand for renewable energy, and increase the supply of renewable energy (ibid). The following policies of the Renewable City Strategy support CEP and/or neighbourhood energy projects:

- Policy B.2.3 requires retrofitting existing buildings and requiring flexibility to achieve energy efficiency requirements, which could be by supporting on-site generation or renewable energy system connection, and

- Policy B.3 supports expanding and developing new renewable energy systems throughout the city (ibid).

The Renewable City Strategy estimates that by 2050, $15 \%$ of municipal energy source for buildings and transportation will be from neighbourhood renewable energy systems (ibid, p. 8). The strategy puts an emphasis on residents and neighbourhoods to produce their own energy and sell what they don't need to promote equity among residents (ibid). The plan also outlines that neighbourhood energy is expected to be able to power non-residential uses, including industrial, commercial, and institutional. This new system is an entirely new business model for 
energy in the city, where neighbourhoods are active producers, users, and vendors of energy products and services.

\section{Renewable City Action Plan}

Vancouver's Renewable City Action Plan goes hand-in-hand with the Renewable City Strategy. It outlines the steps and appoints responsible parties to get the strategy implemented and reach targets. By some definitions the Renewable City Strategy and Renewable City Action Plan could collectively be considered Vancouver's CEP, as Vancouver lacks one single CEP document, but rather has a collection of many policies and programs that work together to enable local energy planning.

\section{Neighbourhood Energy Connectivity Standards Design Guidelines (2014)}

These required design standards apply to buildings over a certain size or development requirement area, which are required to connect to district energy systems. They name priority areas within the city for neighbourhood energy projects based on density and anticipated growth potential. Though not policies, these technical guidelines address how neighbourhood energy (also known as district energy) are to be implemented, and demonstrate Vancouver's encouragement to developers to consider energy strategically in their design (City of Vancouver, 2014).

\section{Low Carbon Energy Systems Policy (2017)}

Vancouver's Low Carbon Energy Systems Policy is a technical approach that applies to new buildings to ensure GHG reductions from new development. It acts as a guideline and enforcement tool as part of the development planning process.

\subsubsection{City of North Vancouver}

\section{Official Community Plan}

The City of North Vancouver's Official Community Plan envisions a complete, efficient, lowemissions community (City of North Vancouver, 2014). The plan sets a target to reduce GHG emissions by $50 \%$ by 2050 (ibid). In Chapter 4, Natural Environment, Energy \& Climate, the practice of energy management is specifically used to develop local sustainable energy sources. Policies direct that:

- use of clean, efficient, and sustainable renewable energy systems be increased (policy 4.1.2a), 
- locally-sourced energy be explored (policy 4.1.2b),

- best practices for new and existing building on-site energy generation be adopted in compliance with City by-laws (policy 4.1.2c),

- $\quad$ support for Lonsdale Energy Corporation ${ }^{9}$ be given in the development and implementation of a Sustainable Energy Strategy (policy 4.1.2d), and

- community energy systems (district and renewable energy) be expanded and increase capacity (policy 1.2.6) (ibid).

\section{0-Year Sustainability Vision}

The City of North Vancouver's 100-Year Sustainability Vision envisions a future where each person produces $80 \%$ less greenhouse gas emissions (The Design Centre for Sustainability, 2009). The plan sets the goal of transitioning to a greenhouse gas neutral energy city, via its own municipal utility, Lonsdale Energy Corporation (ibid). The plan's two critical elements are a significant reduction in energy consumption, and a significant shift to renewable, low-carbon energy sources. This will be substantially supported by the Lonsdale Energy Corporation's district energy system within the city.

\subsubsection{Markham}

\section{Official Plan}

Markham's Official Plan shows an embedded core of sustainability throughout (City of Markham, 2014). The policies are framed around sustainable growth, urban design, economy, and services and utilities (ibid). The themes are to identify opportunities for on-site energy generation, district energy and renewable energy, require CEPs for all Secondary Plans, and encourage the city to work with the Markham District Energy utility to be a leader in design, development, and use of CEP (ibid). Policies include:

- a goal to build complete, sustainable, compact communities, as outlined in policy 2.2.2.,

- encouragement of eco-industrial activities in business parks including cogeneration district energy, as outlined in policy 5.1.1.8,

9 The City of North Vancouver's owned and operated district energy utility. 
- encouragement of alternative energy systems and renewable energy systems in agricultural areas to minimize the environmental impact of agricultural operations, as outlined in policy 5.2.1,

- mandate to plan development sustainably, through measures such as energy efficiency and conservation, as outlined in policy 6.2.2,

- creating a culture of energy conservation by requiring CEPs in all secondary plan areas, which among other things, identify opportunities for on-site energy generation and renewable energy options, as outlined in policy 6.2.2.3,

- the requirement to use the planning process to evaluate sustainable development best practices including conservation and facilitation of future on-site renewable energy systems, as outlined in policy 6.2.3.1, and

- specification for developers and the city to work with Markham District Energy in the design and development of community energy systems in Markham, as outlined in policy 7.2 .3 (ibid).

\section{Greenprint - Markham's Community Sustainability Plan}

The Greenprint plan is Markham's 50-100 year sustainability plan (Markham, 2011). It is a holistic framework of thinking, of which energy is just one part. The Energy \& Climate section outlines a plan for a carbon neutral city that generates local renewable energy, which presents an opportunity for sustainability, resilience, and business opportunity. 


\section{Part 4 - Methodology}

The methodology for this research was a comparative analysis of the four CEPs and their respective municipal policy frameworks. The four municipalities were chosen based on interest and comparability. However, this task was not as simple as comparing four policies, as each municipality undertook the process of CEP differently, and even interpreted the meaning of CEP in different ways. Within Toronto, the Scarborough Centre Community Energy Plan was selected because it represents a diverse, mixed-use, and growing neighbourhood (City of Toronto Environment \& Energy Division, 2014). Vancouver, North Vancouver, and Markham did not require a specific site or neighbourhood to be chosen as their policies apply city-wide. Markham's plan is a Municipal Energy Plan (MEP), not a CEP. The difference is that the MEP is the strategy for the entire city. Smaller scale, neighbourhood CEPs are expected to be published in the coming years in Secondary Plan areas.

In the case of Vancouver, there was not one centralized CEP to study. The policies were broken up into several documents that have been published over a decade. This includes the Neighbourhood Energy ${ }^{10}$ Strategy and Energy Centre Guidelines (2012), Renewable City Strategy 2015-2020 (2015), Renewable City Action Plan (2017), Greenest City Action Plan (2015), Zero Emissions Building Plan (2016), and Low Carbon Energy Systems Policy (2017). Although each municipalities' CEP had to be considered among the network of other sustainability, development, and energy plans, Vancouver's was particularly unique in this aspect. That is because the components of CEPs: energy conservation, efficiency, and generation were spread out among all of these plans, with no one central energy plan that captured all of the elements of a CEP in one document. Although this is not traditional CEP, Vancouver was still chosen because it is recognized as a leader in municipal environmental action. The municipalities' processes and methods of environmental and energy planning aligned with those of CEP.

10"Neighbourhood energy" in Vancouver's context is referred to as the local, neighbourhood-scale energy utility projects and district energy systems. Neighbourhood energy in Vancouver should be interpreted as physical infrastructure, not a type of plan or policy. 
A policy comparison was undertaken to examine several indicators of the CEPs. These included

(2) year published,

(2) scale (neighborhood or city-wide),

(2) focus (conservation, efficiency, and/or generation),

(2) emissions target,

(2) expected future conditions (namely growth),

(2) implementation tools (including land use, planning approvals, etc.),

(2) evaluation methods.

These factors were chosen to give a good understanding of CEP in each of the municipalities, and find elements on which to compare the CEPs to each other and to the best practices found in the literature research.

Additionally, interviews with key Subject Matter Experts (SEM) at the City of Vancouver, City of Toronto, and City of Markham were conducted in person and over the phone to understand the conditions that the municipalities faced in implementing their CEPs, particularly areas that are not included in the written documents. The professional experience of each SME was the only information obtained and used. It was confirmed by the Ryerson Ethics Approval Board that ethics approval was not required for this type of research. The City of North Vancouver was not able to undertake an interview within the timeframe of this MRP. A list of general questions asked can be found in Appendix A. 


\section{Part 5 - Results and Discussion}

\subsection{General Overview and Conditions}

This section will review the following aspects of each of the municipalities CEP:

- Age or time period of the plan(s),

- Scope and scale of the plan(s),

- Area of focus (conservation, efficiency, generation) of the plan(s),

- Motivating factors for establishing local energy planning, and

- Municipality owned and operated energy utilities.

The oldest plan examined was the City of North Vancouver's Community Energy and Emissions Plan (CEEP), which was published in 2010. Next is Vancouver's Neighbourhood Energy Strategy and Energy Centre Guidelines, 2012. Next the Scarborough Centre Community Energy Plan, published in 2014. However, the City of Toronto's first CEP was published in 2010 for the Lawrence-Allen area. Most recently published is Markhams MEP, published in 2017.

\section{Scope and Scale of Community Energy Plans}

In terms of scope and scale, in general terms, all municipalities addressed energy planning at a city-wide scope, though the combination of exactly which policy addressed which scale varied. All plans had some form of local, place-based planning, though to varying degrees. Both Toronto and Markham's MEPs are intended to correspond with Secondary Plans. Markham's SME identified that the York Region Official Plan requires that each Secondary Plan area have its own CEP. Vancouver's Neighbourhood Energy Strategy was particularly focused on the three Target Areas: the downtown core, Cambie Corridor, and Broadway Corridor (City of Vancouver General Manager of Engineering Services, 2012). North Vancouver's CEEP mentions the concept of "sustainability districts" without elaborating any further details (City of North Vancouver, 2010). Overall, none of the municipalities only took on city-wide energy planning, all have broken down by neighbourhood or area within the city. Vancouver and Toronto (Scarborough Centre) both took a heavy emphasis on site-specific planning as well, focusing on individual developments and rezoning projects. This was reflective of the emphasis on building energy use in both plans. 


\section{Areas of Focus of Community Energy Plans}

With regard to the area of focus, as previously mentioned there are three main components to energy planning: conservation, efficiency, and generation. The City of North Vancouver and Markham both focused on all three areas. As mentioned above, Vancouver focused on all three areas, though spread out over several policies and plans. Because of the focus on neighbourhood energy utilities, generation was a top consideration in the Neighbourhood Energy Strategy and Guidelines, and supported in the Zero Emissions Building Plan, and supporting Low Carbon Energy Systems Policy. The Greenest City Action Plan 2015-2020 recognizes that the number one action to take towards a renewable city is to eliminate dependence on fossil fuels by first reducing overall demand, then to increase the use and supply of renewable energy (City of Vancouver, 2015a, p. 9-13). The Scarborough Centre CEP was heavily focused on conservation and efficiency, with only a small mention of energy generation or even district energy, but no plans were put in place besides a vision (City of Toronto, Environment \& Energy Division, 2014). Overall, all municipalities considered to one degree or another conservation, efficiency, and generation. Scarborough explored feasibly implementing on-site energy generation the least. However, the Toronto SME identified that because the Scarborough Centre CEP allows developers to identify the best value and methods for achieving the goals of the CEP, that connection to district energy or other generation methods might be implemented in the area if those are found in the Energy Strategies to be worthwhile. A less prescriptive CEP allows for flexibility and context-specific design for each individual development in Scarborough Centre.

\section{Targets of Community Energy Plans}

When it came to ambition and goal setting, three of the municipalities - City of North Vancouver, Markham, and Vancouver, aim to be net-zero in terms of GHG emissions. Markham and Vancouver have set this milestone by 2050, and the City of North Vancouver by 2107, the city's 200th birthday (City of Vancouver, 2015a; City of Markham, 2017; City of North Vancouver, 2010). Toronto's had the least ambitious targets, with a goal of reducing greenhouse gas emissions to $80 \%$ of 1990 levels by 2050 . The Scarborough Centre CEP did not contain more ambitious goals than the city. However, another CEP in Toronto - the Port Lands, which is managed by Waterfront Toronto, does have a net-zero emissions target (City of Toronto Environment and Energy Division, 2017). The different targets from CEP to CEP, and Secondary Plan to Secondary Plan within Toronto reflect the reality of place-based planning. In 
a neighbourhood like the Port Lands, which is largely unbuilt and will be developed in a master planned, ground-up fashion, it is possible to incorporate high targets because they can be implemented as the site is built. However, for large neighbourhoods with existing residents and businesses, a large scale shift can be too disruptive to implement, and a slower, more phased transition is required in making progress towards reducing GHG emissions, such as Scarborough Centre. In all cases, compared to Canada's target of reducing GHG emissions to $30 \%$ below 2005 levels by 2030, it appears that the net-zero goals all exceed this requirement. Toronto's longer term goal to reduce GHG levels $80 \%$ by 2050 also exceeds the federal level's goal.

\section{Motivating Factors and Conditions for Developing CEPs}

All three SMEs identified concerns about climate change and the environment as a key motivating factor for undertaking municipal energy planning. Not only is a reduction in emissions motivated by the higher level government commitments, but it's also motivated by the local residents who have shown their support for climate action. The SME in Toronto identified that the Scarborough Centre CEP was non-controversial because it did not specify exact mandates, but was rather a framework of thinking, and it was very well received by the population. Similarly in Markham, the SME identified that the population was represented by a strong, progressive city council that wanted to understand the impacts of climate change on Markham and endorsed the municipal sustainability plan. According to Vancouver's SME, Vancouver has a long history of bipartisan support on environmental issues and climate action, which has been long supported by the public.

Another key condition that all of the municipalities had in common was that there was forecasted population growth, which will be accommodated through intensification, density, and some form of vertical, mixed-use growth. All four of the municipalities examined cited this growth as a reason for energy planning, and specifically for areas where growth was directed. Additionally, all three SMEs identified growth as a motivation for local energy planning.

Markham's population is expected to grow 43\% by 2050 (City of Markham, 2017). Markham's MEP also outlines the projected growth of jobs, residential and commercial floor space, and ultimately energy use (ibid). Markham is in a unique position because it is planning to accommodate growth both through intensification and greenfield development. Markham 
contains two provincially designated Urban Growth Centres ${ }^{11}$ : Langstaff Gateway and Markham Centre (Ministry of Municipal Affairs and Housing, 2017). Just over half (54\%) of Markham's projected growth is planned greenfield development, however, Markham's Official Plan emphasizes intensification and development of local urban centres (City of Markham, 2017, p. 158). This pattern results in a different land use system and sustainability planning strategy than the already intensely urbanized cities of Vancouver, City of North Vancouver, and Toronto. Markham's low-density growth areas may also impact the ability to plan for district energy, shared costs of neighbourhood utilities, and other low-carbon planning tools such as public transportation. However, the other municipalities do have existing low-rise, sparsely populated neighbourhoods already, so low density areas may not impact Markham any more than other municipalities.

In Toronto, Scarborough Centre is also a provincially designated Urban Growth Centre ${ }^{12}$ (City of Toronto Environment \& Energy Division, 2014). As with Markham, the City of Toronto also outlines the amount and type of development projected to occur in terms of square feet of construction and designated land uses - growth projections total a $260 \%$ increase in floor space in the area between 2014 and 2041 (ibid, p. 11). Urban growth is such a major theme of the CEP that an entire chapter is titled "Powering Growth."

The City of North Vancouver's CEEP outlines that it will follow Smart Growth principles to accommodate an expected residential growth rate of $1 \%$, and commercial and industrial growth rate of $1.25 \%$ per year until 2050 , all within the already established urban area (City of North Vancouver, 2010). The City of North Vancouver is the only CEP without specifically targeted sub-areas ${ }^{13}$. However, this may be partly due to the small size of the municipality, and the expected growth throughout it. Additionally, the CEEP does include density mapping which clearly shows intensification around the lower Lonsdale area, though no special site-specific

11Both Langstaff Gateway (which is shared with neighbouring municipality Richmond Hill) and Markham Centre have growth targets of 200 residents and jobs per hectare (Ministry of Municipal Affairs, 2017). This will require a population growth of $669 \%$ in Markham Centre, and 567\% population increase in Langstaff Gateway, based on 2006 population numbers to reach their target by 2031 (Neptis Foundation, 2013; Ministry of Municipal Affairs and Housing, 2017).

12Scarborough Centre's provincially designated growth target is 400 residents and jobs per hectare. To meet this target, Scarborough Centre will be required to increase population by 23,000 residents and 40,000 jobs in the area (City of Toronto Environment \& Energy Division, 2014; Ministry of Municipal Affairs, 2017).

13Besides the "Sustainability Districts" mentioned in the CEEP, but left undefined. 
energy policy is proposed. This density shown represents a walkable urban neighbourhood with Smart Growth and Complete Community principles.

In Vancouver, the Neighbourhood Energy Strategy includes three Target Areas: the downtown core, Cambie Corridor, and Broadway Corridor (City of Vancouver General Manager of Engineering Services, 2012). Target Areas are selected because their potential for carbon reduction is highest in the city (ibid). The four criteria for selection were as follows:

1. target areas are within service areas of existing neighbourhood energy utility systems,

1. target areas contain high existing and projected development density and a mix of uses,

2. target areas contain a number of major development and rezoning projects, and

3. target areas contain existing natural gas heated buildings that could be connected to new neighbourhood energy projects.

The strategy succinctly sums up the concept of pairing high-growth areas with energy planning by stating, "...a variety of initiatives that range from deployment of electric vehicles to increased deployment of cycling infrastructure are being implemented to ensure air quality improvements continue in light of population and economic growth" (ibid, p. A-5). Overall, growth was seen as a determining and motivating factor for undertaking an energy and emissions planning process in each of the municipalities.

The final major similarity present in all four municipalities is that they all own and operate energy utilities. This is a major commonality, though the degree to which the utility impacted the municipal energy planning varies greatly between the cities. In Toronto, Toronto Hydro received no mention whatsoever in the Scarborough Centre CEP (City of Toronto Environment and Energy Division, 2014). However, to the North in Markham, Markham District Energy Inc., plays an integral part of the implementation of the city's MEP. Renewable energy generation by Markham District Energy Inc. is already contributing to Markham's climate action, and expansion of the system is planned. Section 13.2.5 "Low carbon city planning" of the MEP even states, " wherever possible, the City should support land-use patterns focussed on complete, compact community design to enable district energy..." (City of Markham, 2017, p. 222).

Similarly, the City of North Vancouver and Vancouver's energy utilities are deeply embedded in their municipal energy planning policies and processes. North Vancouver's CEEP specifically 
aims to meet its climate goals through the expansion of the Lonsdale Energy Corporation, the city-owned utility (City of North Vancouver, 2010, p. 6). In the CEEP's Energy Supply plans, every action presented involved a requirement to work with the Lonsdale Energy Corporation. Vancouver's Greenest City Action Plan includes an action to expand the Neighbourhood Energy Utility (City of Vancouver, 2015a). In the Zero Emissions Building Plan, one of the options that developers can undertake to reach the GHG targets is to connect to Neighbourhood Renewable Energy System, which is also a key area in which the municipality-owned utility becomes a key player.

\subsection{Municipal Roles}

As seen in Section 3, five municipal roles were identified in the general literature on CEP:

1. Plan integrated, sustainable cities.

1. Turn plans and visions in to action.

2. Empower the community and stakeholders.

3. Highlight local benefits and value.

4. Campaign for greater support of CEP to other levels of government.

In this section, the four municipalities will be evaluated for their efforts in these roles.

Plan integrated, sustainable cities.

As seen in Section 2.2, each of these municipalities has a robust network of plans that support climate action. The degree to which they specifically support energy planning, however, varies, as does the degree to which the CEP (or closest document) addresses integrated planning. For example, the City of North Vancouver's CEEP includes strategies for the following sectors: land use planning, buildings, energy supply, and urban agriculture and landscape (City of North Vancouver, 2010). Markham's MEP also focuses on low carbon city planning as an integrated planning theme (City of Markham, 2017). Although the Scarborough Centre CEP focuses largely on building energy demand in a specific neighbourhood, it is designed as part of a larger system of integrated planning laid out in TransformTO (which includes goals relating to buildings, energy, transportation and waste) and therefore is part of an integrated, sustainable city. Similarly in Vancouver it is clear that energy planning is one facet of the larger municipally-led 
climate actions outlined in the Renewable City Strategy, and demonstrated by the 10 goals of the Greenest City Action Plan.

\section{Turn plans and visions in to action.}

The second role, to turn strategies into action plans, has been adopted to some degree by each of the four municipalities. These include various policies, financial incentives, and planning and development requirements. The City of North Vancouver's Low Carbon Zone land use tool, and accompanying Low Carbon Zone Design Guidelines (now referred to as Sustainable Development Guidelines) provide guidance for developers for how to build to meet the requirements of the CEEP (City of North Vancouver, 2010; 2017). The Green Buildings Program (now called the Energy Efficient Building Program) at the City of North Vancouver is another support provided by the city to help developers contribute towards meeting climate targets (City of North Vancouver, n.d.). Using the zoning by-law, new buildings are required to be Net-Zero Energy Ready, a level above what the BC Building Code requires. Additionally, financial incentives are provided to support energy-efficient building retrofits (ibid).

Additionally, the City of North Vancouver's action plan is broken down into senior government actions, and local government actions (City of North Vancouver, 2010). Local actions include smart growth policies, transit, pedestrian, and bike improvements, local building code improvements for new construction and retrofits, onsite renewable energy, district energy expansion and decarbonization, and improvements to the local waste system (ibid). Each of these local actions is broken down into specific steps, funding models, and even partnership opportunities with other levels and jurisdictions of government who can provide value (ibid). In addition to these specific measures, the CEEP also directs the annual budget to integrate the life cycle cost and carbon quantification of capital projects and make consideration to energy and the environment in the city's procurement process (ibid).

The City of Vancouver also employs a zoning tool - Energy Centre Zoning (City of Vancouver, 2014). This enables the already established development permitting and operating agreement process to activate the strategies of the neighbourhood energy utility (ibid). Essentially this implementation plan relies on developers to present to the city their plans to comply with the Neighbourhood Energy Centre Guidelines as a condition of their approval, and demonstrate their consideration for low-carbon energy. The detailed plans required will contribute to the sustainable practices of the city and ensure ongoing compliance (ibid). The Guidelines are a 
practical set of tools to determine where and how local energy utilities can be installed in neighbourhoods. Vancouver's more recent Zero Emissions Building Plan takes a similar approach, setting the target for building GHG emissions, and allows developers to meet those targets in whichever way works best for them. The plan outlines four strategies that the City will undertake to ensure this is implemented: by setting the GHG limits, by providing leadership and demonstration on city-owned buildings, by catalyzing leading developers, and by building capacity within the building industry, which involves removing barriers, sharing knowledge, and developing skills (City of Vancouver Planning, Urban Design and Sustainability Department, 2017). The Low Carbon Energy System Policy ensures that this plan is implemented through development approval conditions to meet the GHG limits set in the Zero Emissions Building Plan (City of Vancouver, 2017).

The City of Vancouver's action plan is set up differently from the other municipalities, with the Greenest City 2020 Action Plan containing most of the actionable items with regards to carbon emissions reduction and renewable energy (City of Vancouver, 2015a). The plan breaks down the actions into Provincial actions -which include renewable energy, fuel sources, and vehicle efficiency-, and local planning actions, which cover buildings, waste, transportation, and neighbourhood energy (ibid). The Neighbourhood Energy Strategy focuses down on two of the planned actions from the Greenest City 2020 Action Plan that fall within the domain of neighbourhood energy: 1) converting existing steam heat systems to low carbon energy sources, and 2) establishing new and expanding neighbourhood energy systems and utilities (ibid).

In Markham, the Markham Green Standard is the key implementation tool. Designed to work alongside the neighbouring Toronto Green Standard, the two policies set the standards for building efficiency and sustainability baselines. The implementation strategy in Markham's MEP includes a suite of tools, including financial incentives such as green bonds and an energy cooperative (Markham, City of, 2017). These tools will be rolled out as the place-based CEPs are also rolled out. Additionally, through integrated low carbon city planning, the municipality has included its target of net-zero emissions to be included in all planning exercises (ibid). This specifically includes requiring CEPs for Secondary Plans ${ }^{14}$, and specific energy strategies for

14 Secondary Plans are smaller scale (neighbourhood, district) policies within a municipalities' Official Plan that provide more specific detail and guidance with regards to land use planning than the overall Official Plan provides. They are implemented as amendments to the Official Plans, making them legally binding. 
major developments (ibid). This also includes a requirement for developers to meet the specifications of the Markham Green Standard as a condition for approval of development proposals (ibid).

Markham's MEP contains actions for each city sector: buildings, transportation, and energy (Markham, City of, 2017). The comprehensive action plan in Markham is presented as a matrix that outlines the program, capacity, financial impact, community engagement, and evaluation of each action (ibid). This style of action planning directly assigns responsibility to a party of department. Markham also goes one step farther than the other municipalities by outlining a communications strategy for the MEP.

In Toronto, the Toronto Green Standard is used as a way to implement low-carbon development. Though Scarborough Centre may lack some of the more sweeping implementation measures such as financial incentives that are used on municipal-scale plans, the CEP uses site-specific planning mechanisms to achieve detailed, site-appropriate implementation. This includes requiring an Energy Plan from developers as part of the Site Plan Control planning mechanism, which requires developers to outline how they have incorporated the recommendations of the CEP in their design (ibid). A benefit of having a such a local context for the Scarborough Centre CEP is that a specific list of energy conservation measures was developed as part of the CEP, which maps out the timeframe and potential impact of a variety of efficiency and conservation measures on the existing and expected building stock in the neighbourhood (ibid). By requiring Energy Plans from developers that propose developments in the area ${ }^{15}$, the municipality essentially leaves the detailed action planning to the developer. Recommended actions for developers include efficient design, energy conservation measures, incorporation of reliable emergency power, on-site renewable generation, combined heat and power, and smart energy grid integration (City of Toronto Environment \& Energy Division, 2014).

Aside from this major action item, a series of next steps was also incorporated into the CEP, which essentially determine the priorities of actions going forward. These include ensuring that municipal buildings lead by action in terms of high-performance design for new facilities, leverage available financial assistance programs, running energy audits on all city properties, aiming to achieve the higher, voluntary Toronto Green Standard standards, and using city

15 For proposals to develop or redevelop a building or group of buildings with a total gross floor area of 20,000 square metres or more. 
facilities to pilot district energy projects (ibid). According to the Scarborough Centre CEP, "area focused and cross-functional CEP implementation has an ability to drive participation in existing energy programs, provide evidence based program improvements, and development of new programs" (ibid, p. 24). The CEP conducts scenario analyses with regards to the GHG emissions savings possible in a variety of scenarios, including the use of district energy. However, these scenario analyses were presented as tools for education and to inform each development's Energy Plan, as still no requirement for district energy requirement is presented.

\section{Empower the community and stakeholders.}

In both BC and Ontario (and across Canada) consultation of public bodies and stakeholders is required in the development of any statutory plans (Planning Act, 1990; Local Government Act, 2015). Although this basic level of engagement was undertaken in all cases, the degree to which the public and stakeholders were educated, empowered, and given decision making authority varies between the cases. It's key to note that the discussion of this section is based on the information in each of the municipalities plans and strategies, and that further research from the perspective of the public and stakeholders may offer a different lens with regards to if community engagement is balanced, accessible, and appropriate.

In the development of the Renewable City Strategy, Vancouver created its Renewable City Action Team, made up of members from government, non-profits, academia, businesses, and utilities, in addition to several other outreach programs. A key pillar in the Renewable City Strategy is "fostering change through influence and advocacy," which includes advocating across sectors, creating partnerships, and advocating for equitable energy projects on First Nations land (City of Vancouver, 2015b). Additionally, a Community Energy Advisory board has been established (ibid). When it comes to empowering the development and construction industry as stakeholders, as discussed above, Vancouver is supportive, open, and flexible in allowing developers to use whatever means they see appropriate to meet the targets of the Zero Emissions Building Plan. As per the Zero Emissions Building Plan, building industry stakeholders were consulted, and further public engagement is required to spread awareness and share information about the real costs and impacts of high performance buildings, and the benefits of zero emissions buildings.

Markham also demonstrated a strong sense of stakeholder empowerment with their established Stakeholder Working Group (City of Markham, 2017). The group was engaged to help guide the 
development of the MEP, identify energy opportunities and solutions to increase local energy production and conservation, identify opportunities for industry partnerships, and engage the broader community (ibid). Additionally, an engagement element was an embedded step in every action item presented in the MEP, as well as a robust communications plan as a part of the implementation strategy for the MEP. Such involved levels of engagement were seen as vital to the implementation of parts of the plan that rely on industry stakeholders, such as the voluntary participation of individual building owners to implementing energy conservation measures or generation on their site (ibid). The plan identifies the following groups: municipal staff, the business community, community groups, institutions, and citizens, all with unique engagement goals and strategies (ibid).

In Toronto, at the city-wide scale, an interdivisional steering committee and Modelling Advisory Group were formed to help develop TransformTO, as well as extensive public engagement (City of Toronto, 2017b). On the neighbourhood scale, building owners and developers were identified as the most critical stakeholders (City of Toronto, 2014). Similarly to Vancouver, in Scarborough Centre the individual developers are empowered to determine how to meet the targets of the CEP through their own designs and methods, and present this plan to the city, rather than a prescriptive approach by the city. This form of empowerment is clearly seen in the Scarborough Centre CEP.

Much less information was available from the City of North Vancouver. "Meaningful engagement" was cited to have happened in the development of the CEEP, as well as input from community stakeholders into the 100 Year Sustainability Vision (City of North Vancouver, 2009; 2010).

Highlight local benefits and value. There are many ways in which these municipalities have shown the value of CEP to the community, whether through case studies or economic value. Demonstrating the local impacts of climate change is a powerful and common method. Generic claims about improved local economy and quality of life were made by all of the municipalities examined.

Vancouver's promotion of its Neighbourhood Energy systems is present throughout many of its plans and strategies, all highlighting the local benefits. The Neighbourhood Energy Design Guidelines and Zero Emissions Building Plan outline benefits including flexible and adaptable 
infrastructure, stable service and pricing, resilience to climate change, and customer comfort (City of Vancouver, 2016; 2014).

The City of North Vancouver also listed benefits in their CEEP including liveability, transportation efficiency, energy security, and local job creation (City of North Vancouver, 2010). Some statistics were given, for example, the economic benefits of sustainable energy investment creates twice as many jobs as equivalent investments in new conventional supply (ibid, p. 19).

Markham also made claims of stable energy pricing, reduced air pollution, and improved health, economic, and social welfare (Markham, 2017). The MEP was direct in stating that "the benefits of increased resilience as a result of the investments in the energy system have not been quantified..." (ibid, p. 15). However, the MEP stresses that the case for making an investment in the MEP is still strong, even without exact quantified benefits.

As for the City of Toronto, one of the goals of TransformTO is to "[maximize] community benefit from climate action" (p. 1). The strategy is intended to deliver on similar generic benefits as the other municipalities plans, such as advancing social equity, improving affordability, strengthening the local economy, creating high quality local jobs, improving public health, and creating resilient communities. Significant research was put into the local benefits of carbon reduction at the city-wide scale, which was presented in the Technical Modelling \& Community Benefit Research (City of Toronto, 2017b). The Low-Carbon Scenario developed as in TransformTO was specifically designed to maximize the community benefits presented in this research. This research presented the most detailed benefits, mapping out exact levels of air quality improvements, estimated savings per household, and person years of employment. In the case of the Scarborough Centre CEP, the local benefits are outlined specific to the neighbourhood and even for each building. Energy resilience in the case of a mass power failure, decreased maintenance and operating costs, and improved comfort are all outlined specifically (City of Toronto, Environment \& Energy Division, 2014).

\section{Campaign for greater support of CEP to other levels of government.}

This municipal role was the least visible in the planning documents. This doesn't mean that it was absent, but it was not written into the documents and policies as published. 
However, Markham and Toronto both participated in the Ontario Municipal Energy Plan Program. The SMEs from Markham and Toronto identified that they didn't face a reason to campaign for greater provincial support in the sense that the province didn't create any direct barriers. The municipalities found that the goals aligned well enough between the two bodies of government. In Vancouver, the SME identified that both federal and provincial funds were used to develop the Neighbourhood Energy Utility. 


\section{Part 6 - Conclusion}

The role of municipalities in climate change action is important yet constantly evolving. Although CEPs remain an important tool for visioning and setting principles, in these cases they have been seen to have taken a step back in importance. This is due to the nature of municipalities working with developers and creating site and context specific energy plans for each development individually. CEPs are still an important step towards getting to the phase where each development can be evaluated separately. They also capture systems thinking and planning at a scale larger than individual developments. However, these plans are not the final step in energy and emissions planning at the municipal scale. In fact, they have been seen to be an early step in the municipalities observed. SMEs in both Vancouver and Toronto pointed to the importance of embedding the principles of low carbon energy systems throughout the planning process, especially in new building design and development. In these two cases, the presence of a CEP was secondary to the understanding and cooperation of developers working with the city to be part of climate solution, not the problem. This non-prescriptive path is beneficial because it creates greater community and industry support while achieving municipal targets.

In the CEPs examined, both municipal-wide policies and strategic local area plans existed, emphasizing the importance of both integrated systems planning, and specific, contextual planning. All of the CEPs recognized that energy conservation, efficiency, and generation were required to be considered in local energy planning. Though different municipalities gave varying weights to each of these aspects, they were at least explored and considered in the analysis in all cases, as these three elements work together in working towards climate action. Municipal energy planning allowed all cities studied to work towards their own climate targets, even varying between neighbourhoods, depending on feasibility. Finally, the motivating factors were similar between the cases as well, which came down to reducing carbon emissions, support for climate action, and municipal population growth.

Of the roles of the municipality, the four municipalities examined were shown to: take on the role of planning integrated, sustainable cities; turn plans into action; empower the community and stakeholders; and highlight local benefits and value. However, the role of creating greater support of CEP from other levels of government was not deemed necessary at this time by the SMEs. 
Based on this research, the following recommendations conclusions can be made.

1. Municipalities should continually evolve, improve, and updates their CEPs based on ongoing feedback from the community and industry stakeholders. This includes conducting ongoing evaluation to see if GHG emissions are reduced, if impacts and benefits are equitably distributed, and if investments are recuperated. If the actions or targets of the CEP are seen to be unrealistic or unfeasible, adjustments should be made accordingly to create continued support for the CEP from residents and stakeholders.

2. CEPs should not be seen as a substitute for precise planning on a building or system scale. Cooperation with individual developers should be seen as an opportunity to turn the principles of the CEP into action.

3. Specific, measurable impacts and benefits for the community affected should be laid out in the CEP. These should go beyond the generic claims of improved environment, economy, and social conditions. Even if the exact benefits are unknown during the development of the CEP, a plan to measure and report them, as well as targets, should be in place.

4. The limits of municipal authority were not seen to be a barrier by SMEs, and it is important that this continues. Municipalities should continue to participate in provincial programs that support CEP and demonstrate the value to the city and province.

5. Municipalities with a history of CEP should share the lessons learned from their successes, failures, and CEP development strategies with municipalities that are new to the CEP process and may lack expertise. 


\section{Areas of Future Research}

CEP is an understudied area of research in Canadian planning policy. The field could benefit from a number of directions of future research, some of which include:

- Widespread studies of the true impacts and benefits of CEP. The benefits cited by each of the municipalities remained generic, with few statistics to back up whether the benefits actually appeared in reality. Researching whether the claimed benefits impact members of the community, and the distribution of those benefits among the population, is be a highly valuable area of research to the communities which host the CEPs.

- The degree to which these plans has worked is difficult to tell because data on GHG emissions that would allow a comparison of a before and after for each of the municipalities does not exist or was not available. However, using the data collected to develop the various CEPs, a baseline has been created and can be used in the future to compare progress and challenges. Additionally, it is important to note that even if all of the targets set in the CEPs are not met, progress towards them at any pace is beneficial, and plans can be improved upon where needed.

- An economic investigation of the return on investment into CEP, and the economic value created from planning low carbon communities would add an important argument in favour of CEP, and spur continued community, industry, and provincial support.

- Research that offered insight into CEP in well-established urban metropolitans compared to smaller, up-and-coming mid-sized cities or towns would be valuable, as the lessons learned from Vancouver and Toronto may not be the same in other tiers of cities. 


\section{Sources}

BC Hydro. (2009, June 9). "Community Energy Planning Best Practices."

https://www.bchydro.com/content/dam/hydro/medialib/internet/documents/power_smart/sustainable_com munities/global_best_practices_model.pdf

Bill 4, 2018. Cap and Trade Cancellation Act, 2018. https://www.ola.org/en/legislativebusiness/bills/parliament-42/session-1/bill-4

Bill 27, 2008. Local Government (Green Communities) Statutes Amendment Act, 2008. http://www.bclaws.ca/civix/document/id/lc/billsprevious/4th38th:gov27-1

British Columbia Climate Action Charter, 2007. Ministry of Community, Sport, and Cultural Development. https://www2.gov.bc.ca/assets/gov/british-columbians-our-governments/local-governments/planning-landuse/bc_climate_action_charter.pdf

Burch, S. (2010). "In pursuit of resilient, low carbon communities: An examination of barriers to action in three canadian cities." Energy Policy, 38(12), 7575-7585. doi:10.1016/j.enpol.2009.06.070

Canada's First Ministers. (2016, March 3). "Vancouver Declaration on Clean Growth and Climate Change." Canadian Intergovernmental Conference Secretariat. http://www.scics.ca/en/productproduit/vancouver-declaration-on-clean-growth-and-climate-change/

CEKAP. (N.d.). "Community Energy Knowledge-Action Partnership." https://www.cekap.ca/index.php

Census Canada. 2016. "Census Profile, 2016 Census [Markham Census Subdivision]." https://www12.statcan.gc.ca/census-recensement/2016/dp-pd/prof/details/page.cfm? Lang $=E \& G e 01=C S D \& C o d e 1=3519036 \& G e 02=C D \&$ Code2 $=3519 \& D a t a=$ Count $\&$ Search Text $=$ markham \&S earch Type=Begins $\&$ SearchPR=01\&B1=All\&TABID $=1$

Census Canada. 2016. "Census Profile, 2016 Census [North Vancouver - City Census Subdivision]." https://www12.statcan.gc.ca/census-recensement/2016/dp-pd/prof/details/page.cfm? Lang $=E \& G e 01=C S D \& C o d e 1=5915051 \&$ Geo2 $=C D \&$ Code2 $=5915 \& D a t a=$ Count $\&$ SearchText $=$ north \%20vancouver\&Search Type=Begins \&SearchPR=01\&B1=All\&TABID=1

Census Canada. 2016. "Census Profile, 2016 Census [Scarborough Centre Federal Electoral District]." https://www12.statcan.gc.ca/census-recensement/2016/dp-pd/prof/details/page.cfm? Lang=E\&Geo1=FED\&Code1=35094\&Geo2=PR\&Code2=47\&Data=Count\&SearchText=Scarborough $\% 20$ Centre\&SearchType=Begins $\&$ SearchPR=01\&B1=All

Census Canada. 2016. "Census Profile, 2016 Census [Toronto Census Subdivision]." https://www12.statcan.gc.ca/census-recensement/2016/dp-pd/prof/details/page.cfm? B1=All\&Code1=3520005\&Code2=35\&Data=Count\&Geo1=CSD\&Geo2=PR\&Lang=E\&SearchPR=01\&Sea rchText=Toronto\&SearchType=Begins $\&$ TABID $=1$

Census Canada. 2016. "Census Profile, 2016 Census [Vancouver Census Subdivision]." https://www12.statcan.gc.ca/census-recensement/2016/dp-pd/prof/details/page.cfm? Lang $=\mathrm{E} \& \mathrm{Geo} 1=\mathrm{CSD} \&$ Code1 $=5915022 \& \mathrm{Geo} 2=\mathrm{CD} \&$ Code2 $=5915 \& \mathrm{Data}=$ Count $\&$ Search Text=vancouver \& SearchType=Begins\&SearchPR=01\&B1=All\&TABID=1

City of Markham. (2011). "Markham's Greenprint Sustainability Plan." https://www.markham.ca/wps/wcm/connect/markham/52740dfc-2b62-47e7-8c64330f9bf0975b/GreenPrint\%2BFINAL\%2BPlan_2011_Accessability.pdf? 
MOD=AJPERES\&amp;CONVERT_TO=url\&amp;CACHEID=ROOTWORKSPACE.Z18_2QD4H901OGV1 60QC8BLCRJ1001-52740dfc-2b62-47e7-8c64-330f9bf0975b-msYXCnX

City of Markham. (2014). "Official Plan."

https://www.markham.ca/wps/portal/home/business/planning/official-plan/01-official-plan

City of Markham. (2017). "Municipal Energy Plan (MEP) - Getting to Zero."

https://www.markham.ca/wps/portal/home/about/sustainability/energy/municipal-energy-plan/municipalenergy-plan

City of North Vancouver. (2009). "100 Year Sustainability Vision." https://www.cnv.org/yourgovernment/sustainability-in-the-city/city-initiatives/100-year-sustainability-vision

City of North Vancouver. (2010). "Community Energy and Emissions Plan."

City of North Vancouver. (2014). 2014 Official Community Plan, By-law No. 8400.

https://www.cnv.org/your-government/official-community-plan

City of North Vancouver. (2017, April). "Sustainable Development Guidelines."

https://www.cnv.org/-/media/city-of-north-vancouver/documents/development-applicationresources/sustainable-development-guidelines.pdf

City of North Vancouver. (N.d.) "Energy Efficient Buildings Initiative." https://www.cnv.org/property-anddevelopment/building-and-development/plans-and-programs/energy-efficient-buildings-initiative

City of North Vancouver Lonsdale Energy Corporation. (N.d.). "Lonsdale Energy Corporation" https://www.cnv.org/city-services/lonsdale-energy

City of Toronto. (2015). "Toronto Official Plan.” Toronto: City of Toronto.

City of Toronto. (2017a). TransformTO Short Term Strategic Business Cases. https://www.toronto.ca/wpcontent/uploads/2017/10/8ec2-TransformTO-Attachment-to-Short-Term-Strategies-Financial-EstimatesJanuary-2017.pdf

City of Toronto. (2017b, November). TransformTO: Climate Action for a Healthy, Equitable, Prosperous Toronto: Results of Modelling Greenhouse Gas Emissions to 2050. Sustainable Solutions Group. https://www.toronto.ca/wp-content/uploads/2017/11/91f6-TransformTO-Modelling-Torontos-Low-CarbonFuture-Results-of-Modelling-Gr....pdf

City of Toronto. (2018). "Toronto Green Standard Version 3." https://www.toronto.ca/citygovernment/planning-development/official-plan-guidelines/toronto-green-standard/toronto-greenstandard-version-3/

City of Toronto Act, 2006, S.O. 2006, c. 11, Sched. A. https://www.ontario.ca/laws/statute/06c11

City of Toronto, City Planning Division. (2017, March). "Zero Emissions Buildings Framework." https://www.toronto.ca/wp-content/uploads/2017/11/9875-Zero-Emissions-Buildings-FrameworkReport.pdf

City of Toronto, Climate, Energy \& Resilience. (2017, April 20). "TransformTO: Climate Action for a Healthy, Equitable and Prosperous Toronto - Report \#2 - The Pathway to a Low Carbon Future." https://www.toronto.ca/wpcontent/uploads/2017/10/99b9-TransformTO-Climate-Action-for-a-Healthy-Equitable-and-ProsperousToronto-Report-2-The-Pathway-to-a-Low-Carbon-Future-Staff-Report-April-2017.pdf 
City of Toronto, Environment \& Energy Division. (2014, March). "Scarborough Centre Community Energy Plan."

City of Toronto, Environment \& Energy Division. (2017, September). "Port Lands Energy Plan: Guidelines for a Net Zero District." https://waterfrontoronto.ca/nbe/wcm/connect/waterfront/ced6be0a-061d-413782c8-91feac66db64/Port+Lands+Energy+Plan_Sep+2017.pdf?

MOD=AJPERES\&CONVERT_TO=urI\&CACHEID=ced6be0a-061d-4137-82c8-91feac66db64

City of Toronto Solicitor General. (2001). "Powers of Canadian Cities - The Legal Framework." https://www.toronto.ca/ext/digital_comm/inquiry/inquiry_site/cd/gg/add_pdf/77/Governance/Electronic_Do cuments/Other_CDN_Jurisdictions/Powers_of_Canadian_Cities.pdf

City of Vancouver. (2014). "Neighbourhood Energy Connectivity Standards Design Guidelines." https://vancouver.ca/files/cov/neighbourhood-energy-design-guidelines.pdf

City of Vancouver. (2015a). "Greenest City Action Plan Part Two: 2015-2020."

https://vancouver.ca/files/cov/greenest-city-2020-action-plan-2015-2020.pdf

City of Vancouver. (2015b). "Renewable City Strategy: 2015-2050."

https://vancouver.ca/files/cov/renewable-city-strategy-booklet-2015.pdf

City of Vancouver. (2016, July 12). "Zero Emissions Building Plan." https://vancouver.ca/files/cov/zeroemissions-building-plan.pdf

City of Vancouver. (2017). "Renewable City Action Plan." https://vancouver.ca/files/cov/renewable-cityaction-plan-november-2017.pdf

City of Vancouver General Manager of Engineering Services. (2012, September 25). "Vancouver Neighbourhood Energy Strategy and Energy Centre Guidelines." Policy Report.

https://vancouver.ca/files/cov/neighbourhood-energy-strategy-and-energy-centre-guidelines-committeereport.pdf

City of Vancouver Planning, Urban Design and Sustainability Department. (2017, November 15). "LowCarbon Energy Systems Policy." https://vancouver.ca/files/cov/Low-carbon-energy-systems-policy.pdf

Clean BC. (2018). "Clean BC: Our Nature. Our Power. Our Future."

https://cleanbc.gov.bc.ca/app/uploads/sites/436/2018/12/CleanBC_Full_Report.pdf

Clean Energy Act, 2010. [SBC 2010] CHAPTER 22.

http://www.bclaws.ca/civix/document/id/complete/statreg/10022_01

Climate Action Toolkit. (n.d.). "Who We Are." https://www.toolkit.bc.ca/who

Community Charter, 2003 [SBC 2003] CHAPTER 26

http://www.bclaws.ca/civix/document/id/complete/statreg/03026_00

Community Energy Association. (2013, August). Community Energy and Emissions Plan Research General Summary of Findings. Natural Resources Canada CanmetENERGY.

https://www.nrcan.gc.ca/energy/offices-labs/canmet/publications/19038

Community Energy Association, et al. (2016, August 5). "Community Energy Planning: Getting to Implementation in Canada." Getting to Implementation.

https://www.ourcommons.ca/Content/Committee/421/FINA/Brief/BR8398218/br-external/Community \%20Energy\%20Planning-Getting\%20to\%20Implementation\%20in\%20Canada-e.pdf

Community Energy Association. (N.d.). "About." http://communityenergy.bc.ca/about/ 
Electricity Act, 1998, S.O. 1998, c. 15, Sched. A. O-Reg 507/18: BROADER PUBLIC SECTOR: ENERGY REPORTING AND CONSERVATION AND DEMAND MANAGEMENT PLANS, current version as of December 31, 2018 https://www.ontario.ca/laws/regulation/r18507

Environment and Climate Change Canada. (2016a). "Pan-Canadian Framework on Clean Growth and Climate Change: Canada's Plan to Address Climate Change and Grow the Economy."

https://www.canada.ca/en/services/environment/weather/climatechange/pan-canadian-framework/climatechange-plan.html

Environment and Climate Change Canada. (2016b). "Federal Actions for a Clean Growth Economy: Delivering on the Pan-Canadian Framework on Clean Growth and Climate Change." Gatineau, QC. https://www.canada.ca/en/services/environment/weather/climatechange/climate-action/federal-actionsclean-growth-economy.html

Environment and Climate Change Canada. (N.d.). "Low Carbon Economy Challenge." https://www.canada.ca/en/environment-climate-change/services/climate-change/low-carbon-economyfund/challenge.html

Environment Commissioner of Ontario. (2018). "Climate Action in Ontario: What's Next? 2018 Greenhouse Gas Progress Report." https://docs.assets.eco.on.ca/reports/climate-change/2018/ClimateAction-in-Ontario.pdf

Evenson, Jeff; Margerm, Katelyn; McDonough, Alexandra. (2013). "Advanced Integrated Community Energy Planning in Ontario: A Primer." Canadian Urban Institute \& QUEST. www.questcanada.org/files/download/be7955f1d8ff501

Green Energy Act, 2009, S.O. 2009, c. 12, Sched. A. O-Reg 397/11: ENERGY CONSERVATION AND DEMAND MANAGEMENT PLANS, as repealed by Electricity Act, 1998, S.O. 1998, c. 15, Sched. A https://www.ontario.ca/laws/regulation/110397

Independent Energy Systems of Ontario. (N.d.). "Indigenous Community Energy Plan Program." http://www.ieso.ca/en/Get-Involved/Funding-Programs/Indigenous-Community-Energy-PlanProgram/ICEP-Overview

Karunathilake, Hirushie; Perera, Piyaruwan; Ruparathna, Rajeev; Hewage, Kasun; Sadiq, Rehan. (2018). "Renewable energy integration into community energy systems: A case study of new urban residential development." Journal of Cleaner Production. 173 (2018) p. 292 - 307. http://dx.doi.org/10.1016/j.jclepro.2016.10.067

Koirala, Binod Prasad, Koliou, Elta, Friege, Jonas, Hakvoorta, Rudi A., Herder, Paulien A. (2016, April). "Energetic communities for community energy: A review of key issues and trends shaping integrated community energy systems." Journal of Renewable and Sustainable Energy Reviews. Volume 56, April 2016, Pages 722-744. https://doi.org/10.1016/j.rser.2015.11.080

Lee, M. (2019, March 15). Personal Communication - email.

Local Government Act, 2015. RSBC 2015. http://www.bclaws.ca/civix/document/id/lc/statreg/r15001_14

MacMillan, D. (2019, February 2). Personal interview.

Markham District Energy Inc. (N.d.). "Markham District Energy Inc." https://www.markhamdistrictenergy.com/ 
Measham, T. G., Preston, B. L., Smith, T. F., Brooke, C., Gorddard, R., Withycombe, G., \& Morrison, C. (2011). "Adapting to climate change through local municipal planning: Barriers and challenges." Mitigation and Adaptation Strategies for Global Change, 16(8), 889-909. doi:10.1007/s11027-011-9301-2

Metro Vancouver. (2011, October). "Integrated Air Quality and Greenhouse Gas Management Plan." http://www.metrovancouver.org/services/air-

quality/AirQualityPublications/IntegratedAirQualityGreenhouseGasManagementPlan-October2011.pdf

Metro Vancouver. (2014, October). "Integrated Air Quality and Greenhouse Gas Management Plan

Progress Report." http://www.metrovancouver.org/services/air-

quality/AirQualityPublications/2014IAQGGMPProgressReport.pdf

Ministry of Energy. (2016, December 2). "Municipal Energy Plan Program." 2016 Ontario West Municipal

Conference Presentation. https://www.amo.on.ca/AMO-PDFs/Events/16OWMC/MEP.aspx

Ministry of Energy. (2017). "Ontario's Long Term Energy Plan 2017: Delivering Fairness and Choice."

Queen's Printer for Ontario. https://files.ontario.ca/books/ltep2017_0.pdf

Ministry of Energy, Mines, and Petroleum Resources. (2007). "The BC Energy Plan: A Vision for Clean Energy Leadership." https://www2.gov.bc.ca/assets/gov/farming-natural-resources-and-

industry/electricity-alternative-energy/bc_energy_plan_2007.pdf

Ministry of Energy, Northern Development, and Mines. (2013). "Municipal Energy Plan Program." https://www.ontario.ca/page/municipal-energy-plan-program

Ministry of Environment, Conservation, and Parks. (2018a). "Preserving and Protecting our Environment for Future Generations: A Made-in-Ontario Plan." Queen's Printer for Ontario. https://prod-environmentalregistry.s3.amazonaws.com/2018-11/EnvironmentPlan.pdf

Ministry of Environment, Conservation, and Parks. (2018b, July 12). "Green Investment Fund." https://www.ontario.ca/page/green-investment-fund

Ministry of Municipal Affairs and Housing. (2017). "Growth Plan for the Greater Golden Horseshoe 2017." http://placestogrow.ca/index.php?option=com_content\&task=view\&id=430\&ltemid=14

Ministry of Municipal Affairs and Housing. (2018, September). Climate Action Revenue Incentive Program." https://www2.gov.bc.ca/gov/content/governments/local-governments/grants-transfers/climateaction-revenue-incentive-program-carip

Natural Resources Canada. (n.d.). "CanmetENERGY." Office of Energy Research and Development. https://www.nrcan.gc.ca/energy/offices-labs/canmet/5715

Natural Resources Canada Council of Energy Ministers. (2009, September). "Integrated Community Energy Solutions." https://www.nrcan.gc.ca/sites/www.nrcan.gc.ca/files/oee/pdf/publications/cemcme/ices_e.pdf

Neptis Foundation. (2013). "Urban Growth Centres." Implementing the Growth Plan for the Greater Golden Horseshoe. http://www.neptis.org/publications/how-will-growth-be-accommodated/chapters/urbangrowth-centres

Ontario Newsroom. (2018, October 31.) "Relief on the Way: Ontario Passes Legislation to End Cap and Trade Carbon Tax: Changes Will Save Families Money; Reduce Gas Prices." Ontario Ministry of Environment. Climate, and Parks. https://news.ontario.ca/ene/en/2018/10/relief-on-the-way-ontariopasses-legislation-to-end-cap-and-trade-carbon-tax.html

Planning Act, 1990. R.S.O. 1990, c. P.13 https://www.ontario.ca/laws/statute/90p13 
Province of British Columbia. (2016, August). "Climate Leadership Plan."

https://www2.gov.bc.ca/assets/gov/environment/climate-change/action/clp/clp_booklet_web.pdf

Province of British Columbia. (N.d.a). "B.C. Climate Action Charter"

https://www2.gov.bc.ca/gov/content/governments/local-governments/climate-action/bc-climate-actioncharter

Province of British Columbia. (N.d.b). "Community Energy \& Emissions Inventory." https://www2.gov.bc.ca/gov/content/environment/climate-change/data/ceei

QUEST. (2016, February). "Community Energy Planning: The Value Proposition, Environmental, Health, and Economic Benefits."

QUEST. (2016, July). "Policies to Accelerate Community Energy Plans: An analysis of British Columbia, Ontario and the Northwest Territories." https://questcanada.org/wp-content/uploads/2018/08/Policies-toAccelerate-Community-Energy-Plans_Full_Report.pdf

QUEST. (N.d.). "About Us”. https://questcanada.org/about-us/

Singh, Birendra (Bob); Roy, Pallavi; Spiess, Thierry, Venkatesh, Bala. (N.d.). "Sustainable Integrated Urban \& Energy Planning, the Evolving Electrical Grid and Urban Energy Transition." Centre for Urban Energy, Ryerson University. https://www.ryerson.ca/content/dam/cue/pdfs/White\%20Paper\%20\%20Urban\%20and\%20Energy\%20Planning.pdf

St. Clair, A. (2019, Mach 19). Personal interview - phone.

The Design Centre for Sustainability. (2009, May). "100 Year Sustainability Vision." City of North Vancouver. https://www.cnv.org/your-government/sustainability-in-the-city/city-initiatives/100-yearsustainability-vision

Tozer, Laura. (2013). "Community Energy Planning in Canada: Successes and Barriers in Implementation" Local Environment, The International Journal of Justice and Sustainability. Volume 18, 2013, p. 20-35. https://doi.org/10.1080/13549839.2012.716406

Trottier Energy Futures Project. (2016, April). Canada's Challenge \& Opportunity: Transformations for Major Reductions in GHG Emissions. David Suzuki Foundation. https://davidsuzuki.org/wpcontent/uploads/2017/09/REPORT-canada-challenge-opportunity-transformations-major-reductions-GHGemissions.pdf

University of Toronto Sustainable Infrastructure Group. (2009). Getting to Carbon Neutral: A Guide for Canadian Municipalities. Toronto Regional Conservation Authority. http://trca.on.ca/dotAsset/68031.pdf

Urban Sustainability Directors Network. (2018, September). "A Guidebook on Equitable Clean Energy Program Design for Local Governments and Partners." https://cadmusgroup.com/wpcontent/uploads/2018/09/Cadmus-USDN-Equitable-Clean-Energy-Guidebook.pdf?utm_referrer=https $\% 3 \mathrm{~A} \% 2 \mathrm{~F} \% 2 \mathrm{Fcadmusgroup} . c 0 \mathrm{~m} \% 2 \mathrm{Fpapers}$-reports\%2Fa-guidebook-on-equitable-clean-energyprogram-design-for-local-governments-and-partners $\% 2 \mathrm{~F}$

Vancouver Charter, 1953 [SBC 1953] CHAPTER 55

http://www.bclaws.ca/civix/document/id/complete/statreg/vanch_01

Wong, J. (2019, February 22). Personal interview - phone.

Wyse, Susan. (2018, July 31.) "'By and For Local People': Assessing How Canadian Local Energy Plans Contribute to the Ideals of Community Energy." York University Faculty of Environmental Sciences. 



\section{Appendix A: Interview Questions}

\section{Development}

- What was the main motivating factor for creating CEPs? Was it growth/capacity, concern for the environment, economic security? (or something completely different?)

- How did the municipality relate to the province in the implementation of the Community Energy Plan (CEP)?

- Were provincial funds used? Were there any barriers from the province that the municipality had to overcome?

- Does the municipality generally have enough jurisdiction to implement all of the goals?

- Have recent changes in Ontario's provincial government had effects on the implementation of the CEP?

- $\quad$ Did implementation play out the way it was outlined in the CEP? What changed in reality during implementation vs. what was expected? Any parts of the CEP that were abandoned?

- Was there community and political support to develop the CEP and its emissions targets?

\section{Implementation}

- What are the biggest barriers to implementing CEPs across the city? Are they mainly social, economic, administrative/institutional, jurisdictional, etc.?

- $\quad$ Do the implementation plans laid out in CEPs usually get implemented as planned? Do they tend to change in reality? Are any parts later abandoned or changed?

- Where do funds come from to implement CEPs? Are any funds from Development Charges earmarked for CEP?

- What are the signs of a successful CEP? How is the success of a CEP measured?

- To what degree does community energy planning contribute to other plans at the City of Markham?

- What are the community reactions to the MEP? Are residents aware of them? Are they proud of them or is there resistance? 